\title{
Fugacity based trophic magnification factors characterize bioaccumulation of cyclic methyl siloxanes within an urban terrestrial avian food web: Importance of organism body temperature and composition
}

Fremlin, K.M. ${ }^{1}$, J.E. Elliott2 ${ }^{2,1}$, P.A. Martin ${ }^{3}$, T. Harner ${ }^{4}$, A. Saini ${ }^{4}$, and F.A.P.C. Gobas ${ }^{1,5}$

${ }^{1}$ Department of Biological Sciences, Simon Fraser University, Burnaby, BC;

${ }^{2}$ Environment and Climate Change Canada, Pacific Wildlife Research Centre, Delta, BC;

${ }^{3}$ Environment and Climate Change Canada, Canada Centre for Inland Waters, Burlington, ON;

${ }^{4}$ Environment and Climate Change Canada, Air Quality Processes Research Section, Toronto, $\mathrm{ON}$;

${ }^{5}$ School of Resource and Environmental Management, Simon Fraser University, Burnaby, BC

\section{Supplementary Information}

PDF; Pages: 21; Tables: 8; Figures: 4

\section{Supplementary Information - Monte Carlo Simulation R} Code

PDF; Pages: 16

\section{Supplementary Information - Metadata}

PDF; Pages: 2

\section{Supplementary Information - Raw Data}

CSV File 


\section{MATERIALS \& METHODS}

\section{Study Area}

The study area included five municipalities in Metro Vancouver, British Columbia, Canada: District of North Vancouver (North Vancouver), City of Vancouver, (Vancouver - West and Vancouver - South), City of Burnaby (North Burnaby - Vancouver East), City of Richmond (Richmond), and City of Delta (Ladner; Figure S1).

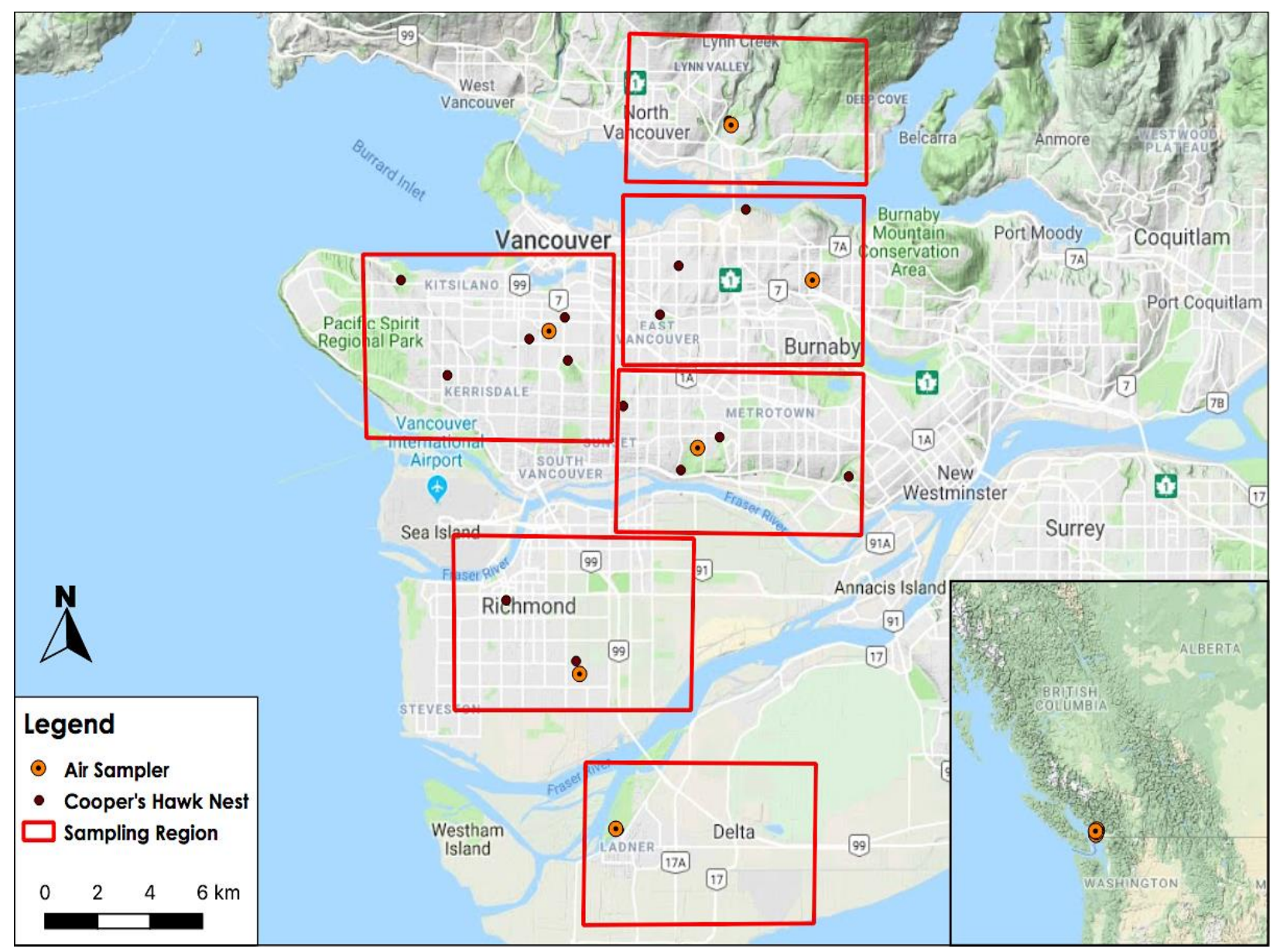

Figure S1. Locations of passive air samplers and Cooper's hawk nest sites across Metro Vancouver, British Columbia (air sampler in Delta overlaps with Cooper's hawk nest). 


\section{Study Design \& Sample Collection}

\section{Air Sampling}

Metal housings (TE-200-PAS, Tisch Environmental Inc., Cleves, OH, USA) with a $14 \mathrm{~cm}$ diameter x $1.3 \mathrm{~cm}$ thick sorbent impregnated polyurethane foam (SIP) disk (TE-104, Tisch Environmental Inc., Cleves, OH, USA) were installed at six locations (Figure S1). SIP disks were impregnated with XAD-4 powder (Amberlite ${ }^{\circledR}$ XAD-4, styrene-divinylbenzene, mesh 20-60, Sigma-Aldrich Co., Product No. 10358). A bucket truck technician installed each sampler $(\mathrm{n}=6)$ approximately $10 \mathrm{~m}$ off the ground onto the exposed trunk of a tree or onto a light standard within $125-900 \mathrm{~m}$ of a Cooper's hawk nest. A $10 \mathrm{~m}$ installation height roughly equates to a $1 \mathrm{~km}$ representative sampling radius or "footprint" (refer to the Supplementary Information of Fremlin et al. ${ }^{1}$ for further sampling details). A generic sampling rate of $4 \mathrm{~m}^{3} /$ day was used for converting mass of cVMS accumulated by SIP disks to corresponding air concentrations ${ }^{2}$.

\section{Biota Sampling}

Cooper's hawk eggs were chosen to represent the apex predator because eggs represent a maternal concentration of contaminants at a given point in time and are frequently used as a matrix for environmental contamination monitoring ${ }^{3-5}$. In addition, concentrations of legacy POPs in eggs are often directly indicative of female body burdens. For example, female herring gulls were reported with egg/liver concentration ratios of roughly equal to one ${ }^{6}$. Furthermore, mean concentrations of $\Sigma \mathrm{PCB}, \Sigma \mathrm{PBDE}$, DDE, and dieldrin in our hawk eggs (15.9 ug/g lipid, $6.61 \mathrm{ug} / \mathrm{g}$ lipid, $27.8 \mathrm{ug} / \mathrm{g}$ lipid, and $2.00 \mathrm{ug} / \mathrm{g}$ lipid, respectively) generally corresponded to liver concentrations in hawks from urban locations of Metro Vancouver $(16.1 \mathrm{ug} / \mathrm{g}$ lipid, $18.7 \mathrm{ug} / \mathrm{g}$ lipid, $47.2 \mathrm{ug} / \mathrm{g}$ lipid, and $3.96 \mathrm{ug} / \mathrm{g}$ lipid, respectively) ${ }^{7,8}$. A possible exception to these observations was for $\Sigma$ PBDE concentrations, due to the extremely high $\Sigma$ PBDE concentrations reported in an adult male (i.e., liver) from Langley, BC (which had the highest $\Sigma$ PBDE concentrations reported in a wild bird at $196 \mathrm{ug} / \mathrm{g}$ lipid) and an adult female from Surrey, BC (104 ug/g lipid) ${ }^{7}$, which introduced bias in the comparison. In addition, in agricultural and mixed (i.e., urban-agricultural) locations across BC, the $\Sigma$ PBDE concentrations in hawk livers were $1.03 \mathrm{ug} / \mathrm{g}$ lipid and $3.27 \mathrm{ug} / \mathrm{g}$ lipid, respectively, so a bit more equivalent to the $\mathrm{PBDE}$ concentrations in eggs from urban Metro Vancouver. Therefore, since these hydrophobic substances had relatively similar concentrations 
in both hawk eggs and livers, we are confident that the cVMS burdens in the eggs are reasonably representative of the burdens in the female hawk.

All frozen biota samples were shipped on dry ice to the National Wildlife Research Centre (NWRC) of ECCC in Ottawa, ON. Sample sizes of each species monitored in the current study are listed in Table S1. Cooper's hawk eggs were homogenized by whisking the yolk and albumen together. Songbirds were defeathered and large keratinized or boney tissues (e.g., beaks, wings, legs, and feet) were removed prior to further processing. All frozen or semi-thawed biota samples (songbirds and invertebrates) were processed by cutting tissues into small pieces and homogenizing them with a ball-mill (Retsch ${ }^{\mathrm{TM}}$ MM400 Mixer Mill, Fisher Scientific). Prior to and after homogenization, samples were stored at $-40{ }^{\circ} \mathrm{C}$.

Table S1. Samples of species from Fremlin et al. ${ }^{1}$ urban terrestrial food web that were analyzed for cVMS in 2017.

\begin{tabular}{llll}
\hline Trophic Guild & Species & Scientific Name & $n$ \\
\hline Apex Predator & Cooper's Hawk & Accipiter cooperii & 9 \\
\hline Secondary Consumers & American Robin & Turdus migratorius & 2 \\
& European Starling & Sturnus vulgaris & 2 \\
& Northern Flicker & Colaptes auratus & 1 \\
& Pigeon/Dove: Rock Pigeon, & Columba livia, Streptopelia & 2 \\
& Eurasian Collared Dove & decaocto & \\
& Sparrow spp.: House Sparrow, & Passer domesticus, Junco & 2 \\
& Dark-eyed Junco, White-crowned & hyemalis, Zonotrichia & \\
& Sparrow, Fox Sparrow, Song & leucophrys, Passerella iliaca, & \\
& Sparrow, Golden-crowned & Melospiza melodia, & \\
& Sparrow, Spotted Towhee & Zonotrichia atricapilla, Pipilo & \\
& & maculatus & \\
& Thrush spp.: Varied Thrush, & Ixoreus naevius, Catharus & 2 \\
& Swainson's Thrush, Hermit & ustulatus, Catharus guttatus & \\
& Thrush & & 4 \\
\hline Primary Consumers & Large Beetles & Pterostichus melanrius, & \\
& & Carabus nemoralis, Carabus & \\
\hline Detritivores & granulatus, Pterostichus sp. & \\
\hline
\end{tabular}

\section{Chemical Analysis}

Air samples were shipped to the Air Quality Processes Research Section of Environment and Climate Change Canada (ECCC), Toronto, ON, Canada and processed and analysed for cyclic volatile methyl siloxanes (cVMS) in the Hazardous Air Pollutants Laboratory (HAPs Lab). SIP disk sample preparation, deployment methods, and chemical analysis have been previously 
published in Shoeib et al. ${ }^{9}$ and Rauert et al. ${ }^{10}$. At the HAPs Lab, each SIP disk was spiked with a surrogate standard solution $\left(10 \mu \mathrm{L}\right.$ of $\left.200 \mathrm{ng} / \mu \mathrm{L}{ }^{13} \mathrm{C}-\mathrm{D} 4 / \mathrm{D} 5 / \mathrm{D} 6\right)$ and then extracted with a 5:1 petroleum ether:acetone (PE:ACE) solvent mixture using an accelerated solvent extraction system (ASE, ASETM 350, Dionex Corporation, Sunnyvale, CA, USA). Each sample extract was concentrated by rotary evaporation (Büchi Rotavapor R-200) to $5 \mathrm{~mL}$ followed by further concentration by nitrogen blow-down to a final volume of $0.5 \mathrm{~mL}$ using iso-octane as a keeper solvent. Samples were subsequently spiked with an internal standard solution $(10 \mu \mathrm{L}$ of $10 \mu \mathrm{g} / \mathrm{mL}$ of d-10 Fluorene) prior to instrumental analysis. The separation and detection of the cVMS (D4, D5, and D6) were performed using gas chromatography-mass spectrometry (GC-MS) (Agilent 5975C, Agilent Technologies, Palo Alto, CA, USA) operating in selective ion monitoring (SIM) mode using electron ionization (EI). Separation of VMS were performed by injecting aliquots of $0.5 \mathrm{~mL}$ on a DB-5 column $(60 \mathrm{~m}, 0.25 \mathrm{~mm}$ inner diameter, $0.25 \mu \mathrm{m}$ film, J\&W Scientific, Folsom, CA, U.S.). Merlin septum was used in all GC instruments to avoid septum bleed.

After homogenization, hawk eggs, avian prey, and invertebrates were shipped to the Canada Centre for Inland Waters of ECCC, Burlington, ON and analysed for cVMS in the National Laboratory of Environmental Testing (NLET). Sample preparation and instrument analysis methods for cVMS were previously published in Lu et al. ${ }^{11}$. Briefly, approximately $1 \mathrm{~g}$ of biota sample was mixed with $10 \mathrm{~mL}$ of methanol and spiked with surrogate standards $\left({ }^{13} \mathrm{C}_{4}-\mathrm{D} 4,{ }^{13} \mathrm{C}_{5}\right.$ $\mathrm{D} 5$, and ${ }^{13} \mathrm{C}_{6}$-D6). The sample was then treated with $15 \mathrm{~min}$ of vortex and $10 \mathrm{~min}$ of centrifugation, and the subsequent solvent was collected in another vial. The methanol extraction was repeated twice, and the combined extract was mixed with $5 \mathrm{~mL}$ of Millipore water and $5 \mathrm{~mL}$ of pentane followed by $5 \mathrm{~min}$ of vortex. The top layer was collected in a glass centrifuge tube and the pentane extraction was repeated three times. The combined extracts were concentrated to $1 \mathrm{~mL}$ using a TurboVap $^{\circledR}$, and $\mathrm{d}_{8}$-Naphthalene was added as an internal standard before instrument analysis. cVMS were quantified using GC-MS (Agilent 6890N, Agilent Technologies, Palo Alto, CA, USA) coupled with a 5975B inert XL EI/CI mass detector and a HP-5MS capillary column $(30 \mathrm{~m} \times 0.25$ $\mathrm{mm}$ ID $\times 0.25 \mu \mathrm{m}$ film thickness $)$. Five $\mu \mathrm{L}(0.75 \mu \mathrm{L} / \mathrm{s})$ samples were injected by cryo-focused mode using a Programmable Temperature Vaporization (PTV) injector. Initial injector temperature was set at $-40{ }^{\circ} \mathrm{C}$, held for $0.75 \mathrm{~min}$ and ramped to $250{ }^{\circ} \mathrm{C}$ at a rate of $600{ }^{\circ} \mathrm{C} / \mathrm{min}$ in $29 \mathrm{~s}$ and held for $12 \mathrm{~min}$. Initial oven temperature was set at $35^{\circ} \mathrm{C}$ for $1 \mathrm{~min}$, ramped to $195^{\circ} \mathrm{C}$ at $20^{\circ} \mathrm{C} / \mathrm{min}$ and then ramped to $290{ }^{\circ} \mathrm{C}$ at $100{ }^{\circ} \mathrm{C} / \mathrm{min}$ and held for $2.5 \mathrm{~min}$. 
Analysis methods for PCB-153 and p,p'-DDE were previously published in Fremlin et al. . Homogenized biota samples were shipped to and analysed for PCB-153 and p,p'-DDE at the Great Lakes Institute for Environmental Research (GLIER), Windsor, ON.

\section{Standards and Chemicals}

At the NLET octamethylcyclotetrasiloxane (D4; CAS\# 556-67-2; purity > $98 \%$ ), decamethyl-cyclopentasiloxane (D5; CAS\# 541-02-6; purity $>98 \%$ ), and dodecamethylcyclohexasiloxane (D6; CAS\# 540-97-6; purity > $98 \%$ ), were purchased from Gelest Inc. (Philadelphia, PA, USA). Isotopically labeled cVMS surrogate standards (Table S2) were purchased from Moravek (purity $>98 \%$; Brea, CA., USA). Solvents such as hexane, dichloromethane, and methanol (CHROMASOLV ${ }^{\circledR}$ Plus grade) were purchased from SigmaAldrich. Diatomaceous earth (J.T. Baker, NJ, USA) and sodium sulphate $\left(\mathrm{Na}_{2} \mathrm{SO}_{4}\right)$ were heated at $600{ }^{\circ} \mathrm{C}$ overnight in a muffle furnace prior to use. ISOLUTE aminopropyl silica gel was purchased from Biotage (Charlotte, NC, USA).

At the HAPs Lab, cVMS were purchased from Gelest Inc (Morrisville, PA, USA) and Sigma-Aldrich (Oakville, ON, Canada).

\section{Quality Control and Assurance}

During field sampling, collection, and preparation, personnel refrained from using personal care products which contained cVMS. Glass materials were used wherever possible to reduce background contamination. All glassware and aluminium foil were cleaned and chemically rinsed prior to use to remove possible background contamination. Any tongs or metal utensils used in the field were cleaned with a $70 \%$ ethanol solution or acetone prior to each use.

At the NLET, three procedural sample blanks were run with separate sets of 9 biota samples each. Each sample was spiked with surrogate standards. The instrument limits of detection (LODs) were defined as the concentration that produces a peak with signal-to-noise $(\mathrm{S} / \mathrm{N})$ ratio of 3 (Table $\mathrm{S} 2$ ). The method detection limits (MDLs) were defined as the mean of the sample blanks $+2 \mathrm{xSD}$ (Table S2). The concentrations and recoveries of cVMS in the sample blanks are listed in Table S3. The mean recoveries of D4, D5, and D6 in the spike-recovery samples were 62 (12 SD) \%, 57 (11 SD) \%, and 59 (13 SD) \%, respectively. All samples were recovery and blank corrected using the MDLs for D4, D5, and D6. 
In addition, four field blanks were collected in May 2019 to monitor for potential contamination to biota samples from handling, processing in a fume hood, transportation, and shipping. Field blank collection consisted of opening an empty, chemically rinsed jar at a Cooper's hawk nest site in one of four sampling regions (North Vancouver, Burnaby, Vancouver, and Delta), filling the jar with Florisil ${ }^{\circledR}(60-100$ mesh, magnesium silicate powder, Sigma-Aldrich Co.), and leaving the jar open for at least 1 minute near the nest site. The filled jars were stored at $-20{ }^{\circ} \mathrm{C}$ prior to handling or shipping. Next, the four jars were opened in the fume hood that was used for invertebrate sorting activities or sample handling and allowed to sit for at least 1 minute. Finally, the jars were shipped on dry ice to NLET and stored at $-20^{\circ} \mathrm{C}$. Unfortunately, due to laboratory delays and the COVID-19 pandemic, we were unable to have the field blanks analysed.

During the installation of the air samples, four field blanks were deployed and collected (i.e., opened, placed in the metal housing, removed, and sealed as a negative control) at three sites: Inter River Park, North Vancouver; Heather St. and W. 20th Ave, Vancouver - West.; and Ladner Harbour Park, Delta. During the air sample processing, two procedural sample blanks were run with separate sets of 5 samples each. Each sample was spiked with surrogate standards. The LOD for each contaminant in the air was determined as $2 \mathrm{xSD}$ of the mean concentration of the field and procedural blanks (Table S2). The MDL for each contaminant in the air was determined as the mean concentration of the field and procedural blanks $+2 x S D$ (Table S2). Data below the MDL were reported as non-detect (ND). Air samples were recovery and blank corrected using the mean of the field and procedural blank concentrations.

Table S2. Limits of detection (LODs) and method detection limits (MDLs) of cVMS at the NLET and the HAPs Lab.

\begin{tabular}{lcccc}
\hline & \multicolumn{2}{c}{ NLET } & \multicolumn{2}{c}{ HAPs } \\
VMS & LOD $(\mathrm{ng} / \mathrm{g} \mathrm{ww})$ & MDL $(\mathrm{ng} / \mathrm{g} \mathrm{ww})$ & LOD $\left(\mathrm{ng} / \mathrm{m}^{3}\right)$ & MDL $\left(\mathrm{ng} / \mathrm{m}^{3}\right)$ \\
\hline Octamethylcyclotetrasiloxane (D4) & 0.24 & 0.58 & 2.41 & 5.07 \\
Decamethylcyclopentasiloxane (D5) & 0.20 & 1.13 & 10.54 & 16.23 \\
Dodecamethylcyclohexasiloxane (D6) & 0.15 & 0.74 & 2.94 & 6.61 \\
\hline
\end{tabular}

Table S3. Recovery corrected concentrations and percent recoveries of cVMS in the procedural sample blanks at NLET.

\begin{tabular}{ccccccc}
\hline & D4 (ng/g ww) & \% Recovery & D5 (ng/g ww) & \% Recovery & D6 (ng/g ww) & \% Recovery \\
\hline Lab Blank 1 & 0.57 & 84.8 & 0.90 & 78.8 & 0.58 & 77.8 \\
\hline
\end{tabular}




\begin{tabular}{lllllll}
\hline Lab Blank 2 & 0.56 & 108 & 0.74 & 82.6 & 0.36 & 95.9 \\
Lab Blank 3 & 0.57 & 97.9 & 0.49 & 86.0 & 0.24 & 97.7 \\
\hline
\end{tabular}

\section{Total Lipid Content Analysis}

Total lipid content in all of the biota samples (Table S7) was previously determined and reported in Fremlin et al ${ }^{1}$. During the chemical analysis for legacy hydrophobic contaminants, approximately $0.25-3.0 \mathrm{~g}$ of biota sample homogenate was ground with diatomaceous earth (J.T. Baker, NJ, U.S.A.), spiked with $25 \mu \mathrm{L}$ of a standard solution, and then extracted with a 50:50 dichloromethane:hexane (DCM:HEX) solvent mixture using an accelerated solvent extraction system (ASE, Dionex ASE 350, CA, USA). Approximately 10\% of this extract was then used in the gravimetric determination of lipid content.

\section{Lipid Composition Analysis}

To determine the relative fraction of polar lipids in each organism or sample, we used a Phospholipid Assay Kit (MAK122, MilliporeSigma, Sigma-Aldrich Corp., Oakville, ONT). Approximately $10-20 \mu \mathrm{L}$ of tissue homogenate was diluted with $90-490 \mu \mathrm{L}$ of $0.5 \%$ Triton $^{\mathrm{TM}}$ X-100 (X100-5ML, MilliporeSigma, Sigma-Aldrich Corp., Oakville, ONT), then $20 \mu \mathrm{L}$ of each sample was transferred in duplicate into a 96 well plate. Standards for colorimetric detection were prepared from a $200 \mu \mathrm{M}$ working solution by first adding $24 \mu \mathrm{L}$ of the $2 \mathrm{mM}$ Phosphatidylcholine Standard to $216 \mu \mathrm{L}$ of deionized water; then five standards with concentrations of $0,30,60,120$, and $200 \mu \mathrm{M}$ were prepared by adding $0,15,30,60$, and $100 \mu \mathrm{L}$ of the $200 \mu \mathrm{M}$ working solution to deionized water for a total volume of $100 \mu \mathrm{L}$ each. Next, $20 \mu \mathrm{L}$ of each standard was transferred in duplicate into a 96 well plate. Then, $80 \mu \mathrm{L}$ of a prepared reaction mix ( $85 \mu \mathrm{L}$ assay buffer, $1 \mu \mathrm{L}$ enzyme mix, $1 \mu \mathrm{L}$ PLD enzyme, and $1 \mu \mathrm{L}$ dye reagent) was added to each well; and the well plate was wrapped in aluminum foil and incubated at room temperature for 30 mins. Finally, the absorbance of the samples and standards was measured at $570 \mathrm{~nm}$ in a microplate reader (SpectraMax ${ }^{\circledR}$ M2e, Molecular Devices, LLC, San Jose, CA). The fraction of total non-polar lipids in each sample was then derived by subtracting the fraction of total polar lipids from the fraction of total lipids. The relative fraction of polar lipids in each sample was derived as a fraction of the total lipid content (i.e., [\% total polar lipid / \% total lipids] x 100). 
We anticipated the relative fraction of polar lipids within the Cooper's hawk eggs to be $33 \%$, which is similar to that found in the eggs of other bird species ${ }^{12-14}$; and we assumed the relative fraction of polar lipids within the tissues of songbirds may be comparable to lean poultry at roughly $30-80 \%{ }^{14-18}$. Lower trophic species in this study such as earthworms were expected to have a relative fraction of $60 \%$ polar lipids ${ }^{19}$. Invertebrates like ground beetles were expected to have a relative fraction of $5-7 \%$ polar lipids ${ }^{20-22}$. The average relative fractions of polar lipids we measured in the Cooper's hawks, songbirds, earthworms, and beetles were 27 (5.7 SD) \%, 34 (18 SD) $\%, 53(29 \mathrm{SD}) \%$, and $4.7(0.65 \mathrm{SD}) \%$, respectively (Table S4).

Table S4. Measured total lipid content (\% TL), total polar lipid content (\% PL), and total nonpolar lipid content (\%NPL) and derived relative fractions of polar lipids ( $\varphi$ PL) and non-polar lipids ( $\varphi$ NPL).

\begin{tabular}{lcccccccccc}
\hline & \multicolumn{2}{c}{$\%$ TL } & \multicolumn{2}{c}{$\%$ PL } & \multicolumn{2}{c}{$\%$ NPL } & \multicolumn{2}{c}{$\varphi$ PL } & \multicolumn{2}{c}{$\varphi$ NPL } \\
Species & Mean & SD & Mean & SD & Mean & SD & Mean & SD & Mean & SD \\
\hline Cooper's Hawk & 5.5 & 0.54 & 1.5 & 0.19 & 4.0 & 0.60 & 27 & 4.5 & 73 & 4.5 \\
European Starling & 4.0 & 0.95 & 1.1 & 0.17 & 2.9 & 0.78 & 28 & 2.4 & 72 & 2.4 \\
Northern Flicker & 3.6 & - & 2.2 & - & 1.4 & - & 61 & - & 39 & - \\
Sparrow & 3.0 & 0.01 & 0.67 & 0.078 & 2.4 & 0.09 & 22 & 2.7 & 78 & 2.7 \\
Large Beetles & 2.6 & 0.39 & 0.24 & 0.22 & 2.4 & 0.59 & 4.7 & 0.80 & 90 & 11 \\
Pigeon & 6.2 & 4.9 & 1.8 & 0.053 & 4.4 & 4.8 & 41 & 31 & 59 & 31 \\
American Robin & 2.1 & 0.50 & 0.95 & 0.12 & 1.2 & 0.37 & 46 & 4.9 & 54 & 4.9 \\
Thrush & 4.2 & 3.6 & 0.45 & 0.13 & 3.7 & 3.7 & 19 & 19 & 81 & 19 \\
Earthworm & 0.79 & 0.34 & 0.36 & 0.022 & 0.43 & 0.34 & 54 & 29 & 46 & 29 \\
\hline
\end{tabular}

\section{Data Analysis}

\section{Fugacity Analysis}

The average daily air temperature in Metro Vancouver, BC reported at the Vancouver International Airport climate station from August to November in 2016 was $12.2(5.65 \mathrm{SD}){ }^{\circ} \mathrm{C}$ and during these months in 2019 it was 13.3 (4.00 SD) ${ }^{\circ} \mathrm{C}{ }^{23}$. Thus, both air sampling periods had an average daily air temperature of roughly $13{ }^{\circ} \mathrm{C}$.

\section{Lipid Equivalent Fractions}

To determine the fractions of total protein and total non-protein, non-lipid organic matter in our lipid equivalent calculation, we measured the amount of total protein in each organism or 
sample using a Bradford method and derived the fraction of non-protein, non-lipid organic matter by subtracting the fractions of total lipids and total proteins from the fraction of dry matter in each sample (Table S7).

For the Bradford assay, approximately $0.1-0.3 \mathrm{~mL}$ of sample homogenate was diluted with $0.1 \mathrm{M} \mathrm{KPO}_{4}$ buffer ( $\mathrm{pH}$ 7.4) with dilution factors ranging from 80 - 375. Six standards for colorimetric detection were prepared from a $0.2 \mathrm{mg} / \mathrm{mL}$ Bovine Serum Albumin (BSA A2153, MilliporeSigma, Sigma-Aldrich Corp., Oakville, ONT) working solution with concentrations of 0, $10,20,40,60,80 \mu \mathrm{g} / \mathrm{mL}$ of BSA in $0.1 \mathrm{M} \mathrm{KPO}_{4}$ buffer. Then, $50 \mu \mathrm{L}$ of each standard and each sample was transferred in triplicate and quintuplicate, respectively, to a 96 well plate. Next, 200 $\mu \mathrm{L}$ of 1/5 diluted Bradford reagent (500-0006, Bio-Rad Laboratories Ltd., Montreal, QC) in deionized water was transferred to each standard and sample well; and the well plate was wrapped in aluminum foil and incubated at room temperature for 5-10 mins. Finally, the absorbance of the samples and standards was measured at $595 \mathrm{~nm}$ in a microplate reader (SpectraMax ${ }^{\circledR}$ M2e, Molecular Devices, LLC, San Jose, CA).

\section{Lipid-Octanol Partition Coefficients}

Poly-parameter linear free energy relationships used to determine $\log K_{\text {lipoct }}$ with solute descriptors from Atapattu and Poole ${ }^{24}$ :

$\log K_{\text {polar lipid-octanol }}=0.202+0.178 E+0.334 S-0.17 B-0.514 V$

$\log K_{\text {non-polar lipid-octanol }}=-0.158+0.138 E-0.026 S-0.68 B+0.296 \mathrm{~V}$

Table S5. Physicochemical properties of cVMS, PCB-153, and $p, p$ '-DDE used in calculations of fugacity capacity $\left(\mathrm{Z}_{\text {lipid }}\right)$ and fugacity $(f)$. Temperatures used in $\log K_{\mathrm{OA}}=\mathrm{A}+\mathrm{B} / \mathrm{T}$ linear regressions included $291 \mathrm{~K}$ (i.e., $18{ }^{\circ} \mathrm{C}$ ) for invertebrates and $313 \mathrm{~K}$ (i.e., $40{ }^{\circ} \mathrm{C}$ ) for birds. $\mathrm{E}, \mathrm{S}, \mathrm{A}, \mathrm{B}, \mathrm{V}$, and $\mathrm{L}$ solvent descriptors were obtained from Ulrich et al. ${ }^{25}$ and used in eqns. 1 and 2.

\begin{tabular}{llcccccccc}
\hline Analyte & $\begin{array}{l}\text { Log } K_{\mathrm{OA}} \\
\text { Regression }\end{array}$ & E & S & A & B & V & L & $\begin{array}{c}\text { Membrane } \\
\text { Lipid } \\
\text { Log } K_{\text {LO }}\end{array}$ & $\begin{array}{c}\text { Storage } \\
\text { Lipid } \\
\text { Log } K_{\text {LO }}\end{array}$ \\
\hline D4 & $-3.37+2282 / \mathrm{T}^{\mathrm{a}}$ & -0.47 & -0.08 & 0 & 0.51 & 2.3448 & 4.473 & -1.20 & 0.13 \\
D5 & $-3.34+2470 / \mathrm{T}^{\mathrm{a}}$ & -0.70 & -0.10 & 0 & 0.50 & 2.931 & 5.242 & -1.55 & 0.28 \\
D6 & $-4.39+3001 / \mathrm{T}^{\mathrm{a}}$ & -0.88 & -0.12 & 0 & 0.74 & 3.5172 & 6.08 & -1.93 & 0.26 \\
PCB 153 & $-6.02+4695 / \mathrm{T}^{\mathrm{b}}$ & 1.80 & 1.40 & 0.06 & 0.14 & 2.0526 & 9.73 & -0.09 & 0.57 \\
DDE & $-7.49+5116 / \mathrm{T}^{\mathrm{c}}$ & 2.18 & 1.74 & 0 & 0.11 & 2.0586 & 9.587 & 0.09 & 0.63 \\
\hline
\end{tabular}

${ }^{a} X u$ and Kropscott ${ }^{26} ;{ }^{b}$ Harner and Bidleman ${ }^{27}$; and ${ }^{c}$ Shoeib and Harner ${ }^{28}$.

Organism Body Temperature 
The average body temperature of many passerine birds typically ranges from $39-43{ }^{\circ} \mathrm{C}{ }^{29}$, and the average body temperature for a Cooper's hawk post-flight is approximately $40^{\circ} \mathrm{C}{ }^{30}$. To simplify our calculations, we assumed a mid-range value of $40{ }^{\circ} \mathrm{C}$ for all of our bird species, particularly since the body temperature of birds can vary by approximately $3-5^{\circ} \mathrm{C}$ depending on the intensity of their activity levels ${ }^{31}$. The preferred temperature of many northern temperate ground beetle species, such as Pterostichus spp., ranges from $15-18{ }^{\circ} \mathrm{C}{ }^{32}$. The optimal temperature for development of most earthworm species ranges from $12-20^{\circ} \mathrm{C}$ and often depends on soil moisture content ${ }^{33,34}$; so the preferred body temperature of the invertebrates in this food web was assumed to be $18^{\circ} \mathrm{C}$.

\section{Respiratory \& Dietary Intake}

The at-rest respiratory rate for Cooper's hawks was assumed to be similar to those for Eurasian sparrowhawks (Accipiter nisus), a conspecific species of the Cooper's hawk, obtained from Gatehouse and Markham ${ }^{35}$. Eurasian Sparrowhawks with bodyweights of $95 \mathrm{~g}, 104 \mathrm{~g}$, and $114 \mathrm{~g}$ inhaled an overall average of $1.7 \mathrm{~mL}$ of air $/ \mathrm{g} \mathrm{hr}$., $1.3 \mathrm{~mL}$ of air/g hr., and $1.2 \mathrm{~mL}$ of air $/ \mathrm{g} \mathrm{hr}$., respectively, and inhaled a maximum of roughly $3.0 \mathrm{~mL}$ of air $/ \mathrm{g} \mathrm{hr}$., $2.5 \mathrm{~mL}$ of air/g hr., and 1.8 $\mathrm{mL}$ of air/g hr. ${ }^{35}$. We assumed the maximum at-rest air flow of $3.0 \mathrm{~mL}$ of air $/ \mathrm{g} \mathrm{hr}$. for the Eurasian Sparrowhawk to be equivalent to the minimum at-rest air flow of a Cooper's hawk since Cooper's hawks are typically larger than Sparrowhawks (e.g., $470 \mathrm{~g}^{36}$ versus $115 \mathrm{~g}^{35}$ ). Thus, the minimum at -est air flow of a Cooper's hawk was estimated as $3.0 \mathrm{~mL} / \mathrm{g} \mathrm{hr} * 95 \mathrm{~g} * 24 \mathrm{hr} / \mathrm{d} * 10^{6} \mathrm{~m} 3 / \mathrm{mL}=$ $0.0068 \mathrm{~m}^{3} / \mathrm{d}$ (Table S5). The maximum respiratory rate for Cooper's hawks was derived from the relationship between bodyweight and maximum oxygen consumption $\left(\mathrm{VO}_{2 \max }\right)$ determined by Bishop ${ }^{37}$ as $\mathrm{VO}_{2 \max }=216^{*} \mathrm{M}^{0.778}$, in which $\mathrm{M}$ is bodyweight $(\mathrm{kg})$ of the hawk. We used an average bodyweight of a female Cooper's hawks $(0.473 \mathrm{~kg})^{36}$ to obtain a $\mathrm{VO}_{2 \max }=0.173 \mathrm{~m}^{3} / \mathrm{d}$ (Table S5). At-rest and maximum respiratory rates for European starlings were obtained from Butler ${ }^{38}$ (Table S5).

The dietary ingestion rate for the Cooper's hawk was based on observations from a male Cooper's hawk in winter $(63 \mathrm{~g} / \mathrm{d}){ }^{39}$ and a female in spring-summer $(70 \mathrm{~g} / \mathrm{d}){ }^{39}$; thus, dietary ingestion rates were assumed to range from $60-75 \mathrm{~g}$ of food/day and were calculated as $70 \mathrm{~g} / \mathrm{d}$ * 
$1 \mathrm{~g} / \mathrm{mL} * 10^{6} \mathrm{~m}^{3} / \mathrm{mL}=7.0 \times 10^{-5} \mathrm{~m}^{3} / \mathrm{d}$ (Tables S5). The dietary ingestion rate for the European starling was based on observations from $\mathrm{Cabe}^{40}$ and ranged from $5-25 \mathrm{~g} /$ day (Table S5).

Concentrations of cVMS used in the dietary flux calculations were based on the sum of proportional average concentrations of the prey items available for cVMS analysis as per $C_{\text {diet }}=$ $\left(\sum_{i=1}^{n} p_{\text {prey } i} * C_{\text {prey } i}\right)$. Weight wet concentrations of prey items were converted to $\mathrm{mol} / \mathrm{m}^{3}$ and then $\log$ transformed. The assumed proportions of the prey items in the diet of the Cooper's hawk were American robin (30\%), European starling (35\%), Northern flicker (2\%), Thrush species (1\%), Sparrow species (22\%), and Pigeon/Dove (10\%) ${ }^{39,41-43}$. The assumed proportions of the prey items in the diet of the European starling were earthworms (15\%) and large beetles (35\%) 40 , 44-46. However, since we did not analyse a full representation of the entire diet of the starling, these proportions were adjusted to $30 \%$ and $70 \%$ to represent the total proportion of starling prey items that were available for cVMS analysis.

To evaluate the relative contributions of dietary and respiratory intake rates in light of uncertainties regarding air inhalation and feeding rates, uptake efficiencies, and chemical concentrations, we used a Monte Carlo simulation. In the Monte Carlo simulation, random values for respiratory and dietary flow were selected from uniform distributions of the maximum and minimum ranges determined from the literature (Table S5). Respiratory uptake efficiency was assumed to be $20 \%, 10 \%$, and $5 \%$ for D4, D5, and D6, respectively, within birds based on inhalation exposure studies in humans and rats 47,48 . Random values for respiratory uptake efficiencies were selected from uniform distributions ranging from $5-50 \%$ for D4 and $5-20 \%$ for D5 and D6. Dietary uptake efficiency in the Cooper's hawk and European starling was assumed to be $80 \%, 50 \%$, and $20 \%$ for D4, D5, and D6, respectively, and were based on dietary exposure of siloxanes in rats and of PCBs in birds ${ }^{49,50}$. Random values for dietary uptake efficiencies were selected from uniform distributions ranging from $70-100 \%$ for D4 and $15-50 \%$ for D5 and D6. Geometric mean concentrations of air $\left(\mathrm{ng} / \mathrm{m}^{3}\right)$ and their associated SD were converted to $\mathrm{mol} / \mathrm{m}^{3}$ (Table S5). Random values for respiratory and dietary concentrations were selected from log normal distributions of the log mean concentration and the log SD (Table S5). The mean flux, standard deviation, standard error, and 95\% confidence limit were subsequently determined from the simulation output. We also examined dietary and respiratory intake with uptake efficiencies of $1 \%$ and $100 \%$ to assess how uptake efficiency extremes may impact mean flux. Refer to the Supplementary Information - Monte Carlo Simulation for the R script used in the analyses. 
Table S6. Range of parameters used in the flux analysis for the Cooper's hawk (COHA) and European starling (EUST).

\begin{tabular}{|c|c|c|c|}
\hline Parameter & Air & Diet & References \\
\hline \multicolumn{4}{|l|}{ Flow (F) } \\
\hline $\mathrm{COHA}$ & $0.00684-0.173\left(\mathrm{~m}^{3} / \mathrm{d}\right)$ & $60-75(\mathrm{~g} / \mathrm{d})$ & $35,37,39$ \\
\hline EUST & $0.0046-0.040\left(\mathrm{~m}^{3} / \mathrm{d}\right)$ & $5-25(\mathrm{~g} / \mathrm{d})$ & $37,38,40$ \\
\hline \multicolumn{4}{|c|}{ Uptake Efficiency (E) } \\
\hline D4 (\%) & $5-50$ & $70-100$ & $47-50$ \\
\hline D5 (\%) & $5-20$ & $15-50$ & $47-50$ \\
\hline D6 (\%) & $5-20$ & $15-50$ & $47-50$ \\
\hline \multicolumn{4}{|c|}{ Concentrations for COHA I- Log Mean (Log SD) } \\
\hline $\mathrm{D} 4\left(\mathrm{~mol} / \mathrm{m}^{3}\right)$ & $-23.14(0.29)$ & $-12.27(0.33)$ & \\
\hline $\mathrm{D} 5\left(\mathrm{~mol} / \mathrm{m}^{3}\right)$ & $-21.89(0.43)$ & $-10.57(0.24)$ & \\
\hline $\mathrm{D} 6\left(\mathrm{~mol} / \mathrm{m}^{3}\right)$ & $-24.83(0.50)$ & $-12.28(0.26)$ & \\
\hline \multicolumn{4}{|c|}{ Concentrations for EUST I - Log Mean (Log SD) } \\
\hline $\mathrm{D} 4\left(\mathrm{~mol} / \mathrm{m}^{3}\right)$ & $-23.14(0.29)$ & $-12.28(0.25)$ & \\
\hline $\mathrm{D} 5\left(\mathrm{~mol} / \mathrm{m}^{3}\right)$ & $-21.89(0.43)$ & $-10.58(0.51)$ & \\
\hline $\mathrm{D} 6\left(\mathrm{~mol} / \mathrm{m}^{3}\right)$ & $-24.83(0.50)$ & $-13.36(0.56)$ & \\
\hline
\end{tabular}

\section{RESULTS \& DISCUSSION}

Contaminant Concentrations in Air and Biota 


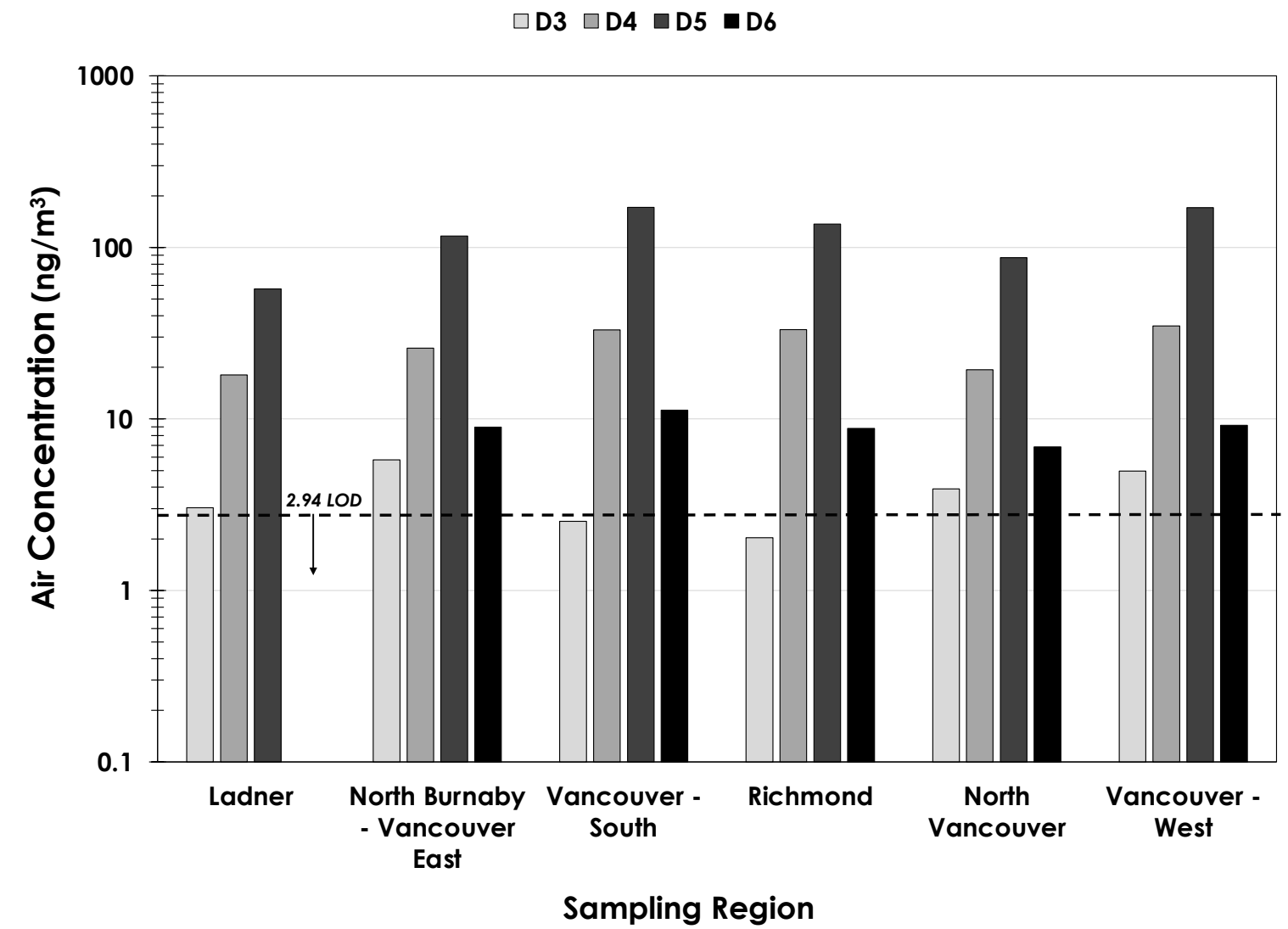

Figure S2. Detected concentrations of cVMS in air samples collected across Metro Vancouver from August to November 2019. Concentration of D6 in air from Ladner was below the limit of detection (LOD; Table S1). 


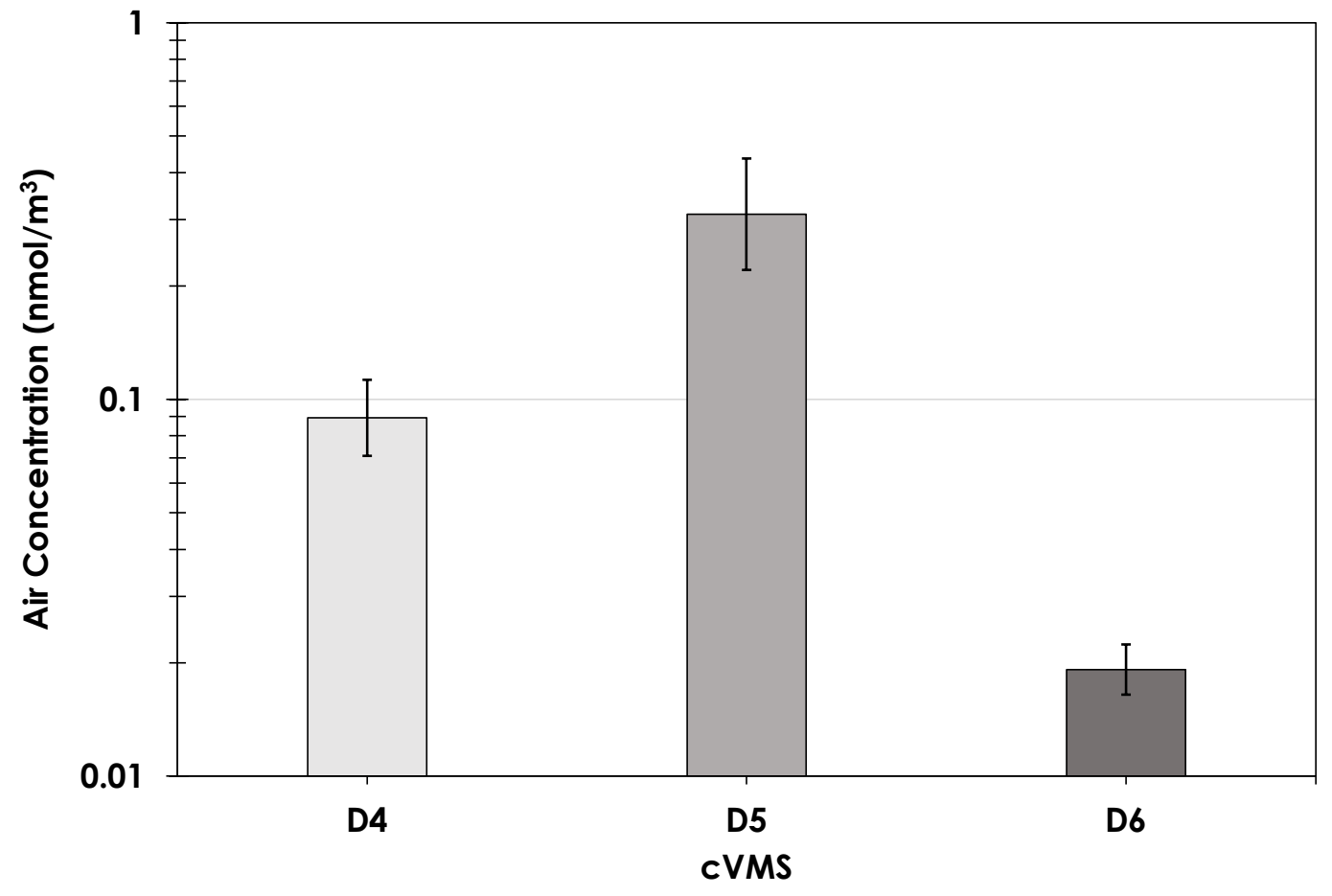

Figure S3. Geometric mean concentrations $\left(\mathrm{nmol} / \mathrm{m}^{3}\right)$ of $\mathrm{cVMS}$ in air samples $(n=6)$ from across Metro Vancouver for the period of August - November 2019. Error bars represent the upper and lower $95 \%$ confidence interval. 


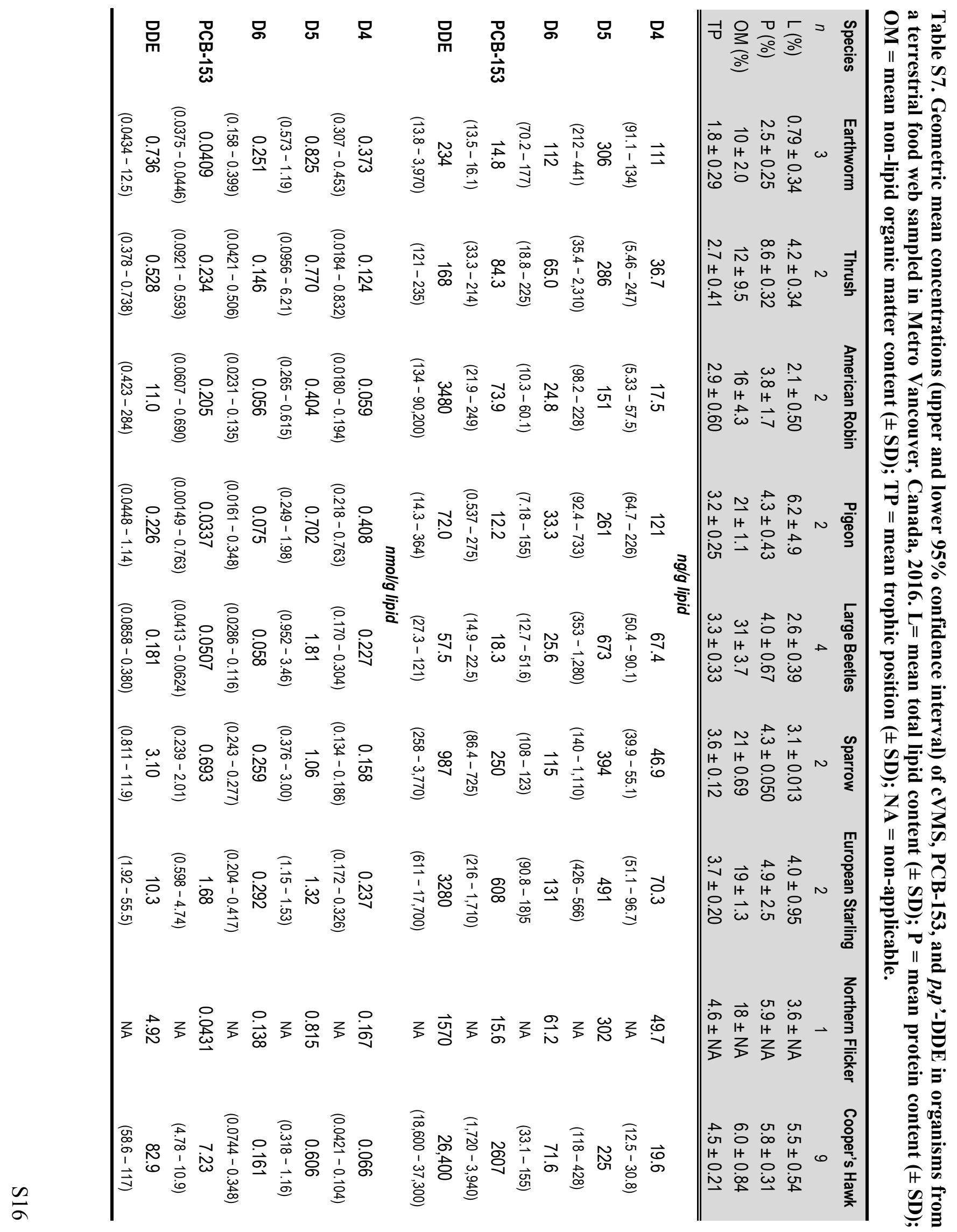




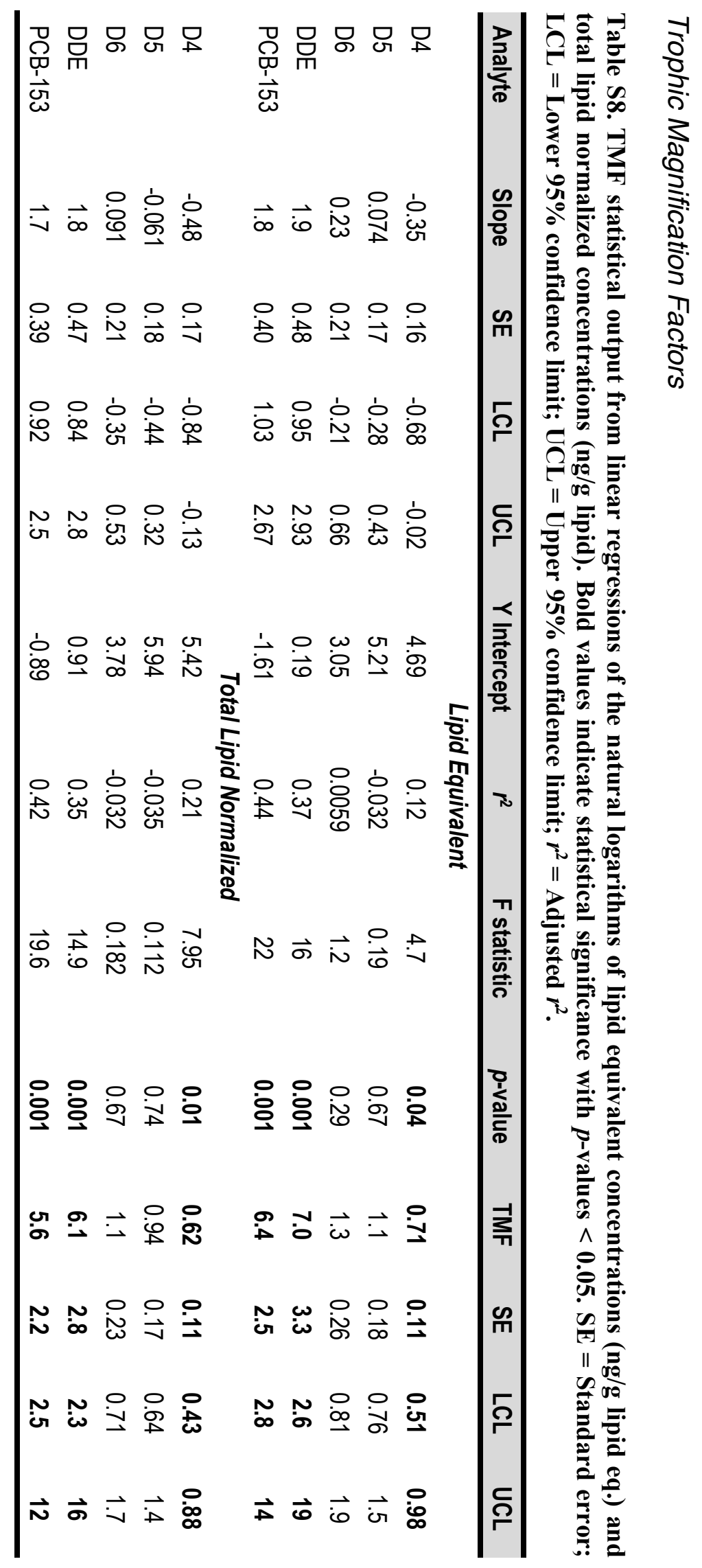


Fugacity Analysis

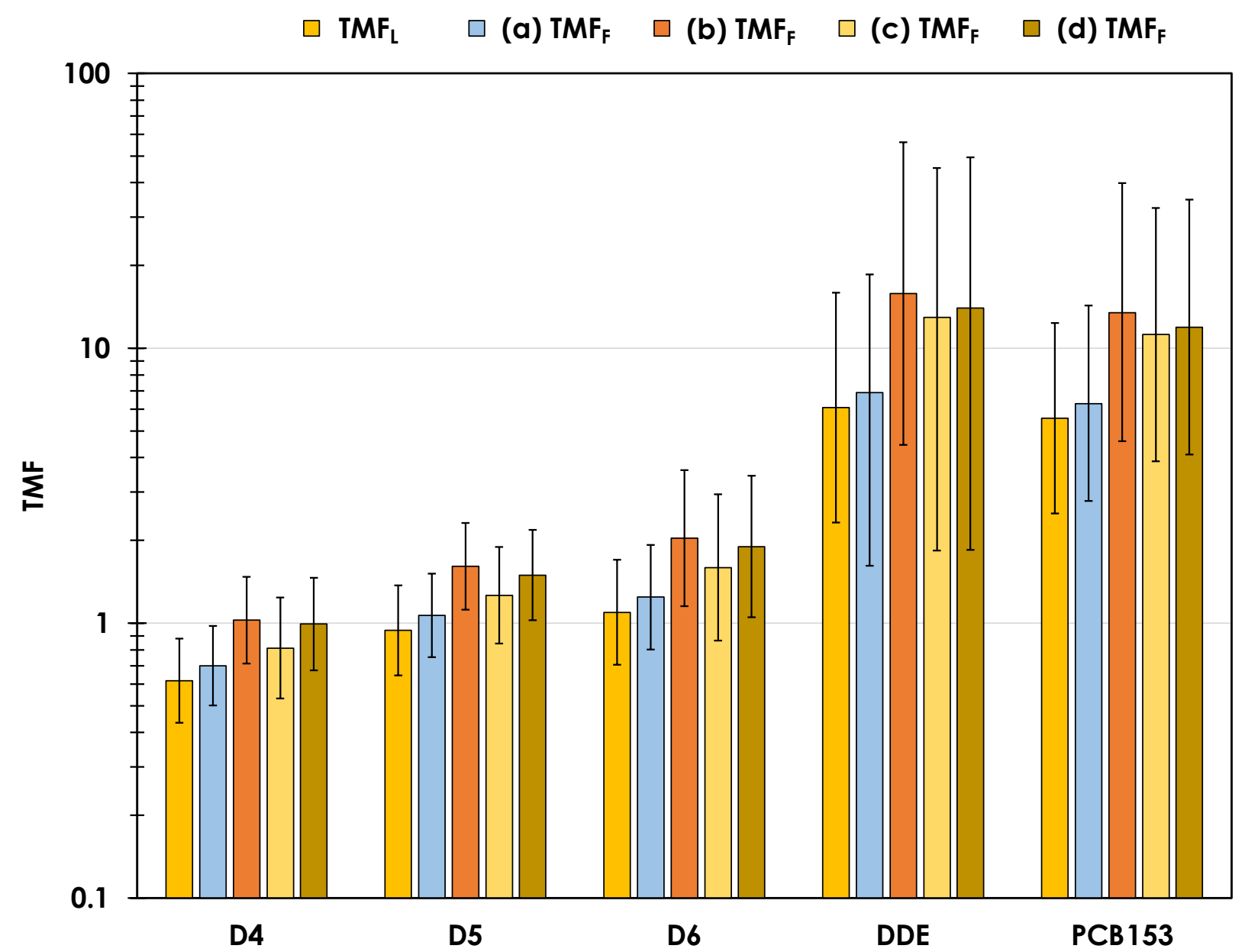

Figure S4. TMFs derived with lipid normalised concentrations $\left(\mathrm{TMF}_{\mathrm{L}}\right)$ compared with (a) fugacitybased TMF $\left(\mathrm{TMF}_{\mathrm{F}}\right)$ derived with all organisms at a temperature of $18{ }^{\circ} \mathrm{C}$ without lipid-octanol partitioning; (b) $\mathrm{TMF}_{\mathrm{F}}$ derived with the associated body temperatures of organisms (i.e., $40{ }^{\circ} \mathrm{C}$ for birds and $18{ }^{\circ} \mathrm{C}$ for invertebrates) without lipid-octanol partitioning; (c) $\mathrm{TMF}_{\mathrm{F}}$ derived with the associated body temperatures of organisms including lipid-octanol partitioning but excluding the lipid equivalent fractions in the organisms; and (d) $\mathrm{TMF}_{\mathrm{F}}$ derived with the associated body temperatures of organisms including lipid-octanol partitioning. Error bars represent the upper and lower $95 \%$ confidence limits. 


\section{References}

1. Fremlin, K. M.; Elliott, J. E.; Green, D. J.; Drouillard, K. G.; Harner, T.; Eng, A.; Gobas, F. A. P. C., Trophic magnification of legacy persistent organic pollutants in an urban terrestrial food web. Science of The Total Environment 2020, 714, 136746.

2. Harner, T.; Mitrovic, M.; Ahrens, L.; Schuster, J., Characterization of PUF disk passive air samplers for new priority chemicals: a review. Organohalogen Compounds 2014, 76, 442-445.

3. Miller, A.; Elliott, J. E.; Elliott, K. H.; Guigueno, M. F.; Wilson, L. K.; Lee, S.; Idrissi, A., Spatial and temporal trends in brominated flame retardants in seabirds from the Pacific coast of Canada. Environmental Pollution 2014, 195, 48-55.

4. Henny, C. J.; Elliott, J. E., Chapter 18, Toxicology. In Raptor Research and Management Techniques. Second Edition, Bird, D. M.; Bildstein, K. L., Eds. Raptor Research Foundation. Hancock House Publishing: Surrey, BC, Canada, 2007; pp 351 - 364.

5. Elliott, J. E.; Martin, P. A., Chlorinated hydrocarbons and shell thinning in eggs of (Accipiter) hawks in Ontario, 1986-1989. Environmental Pollution 1994, 86 (2), 189-200.

6. Elliott, J., E. ; Bishop, C. A., Cyclodiene and Other Organochlorine Pesticides in Birds. In Environmental Contaminants in Biota, Beyer, W. N.; Meador, J. P., Eds. CRC Press: Boca Raton, FL, USA, 2011; pp 447-475.

7. Elliott, J. E.; Brogan, J. M.; Lee, S. L.; Drouillard, K. G.; Elliott, K. H., PBDEs and other POPs in urban birds of prey partly explained by trophic level and carbon source. Sci Total Environ 2015, 524525, 157-65.

8. Brogan, J. M.; Green, D. J.; Maisonneuve, F.; Elliott, J. E., An assessment of exposure and effects of persistent organic pollutants in an urban Cooper's hawk (Accipiter cooperii) population. Ecotoxicology 2017, 26, $32-45$.

9. $\quad$ Shoeib, M.; Schuster, J.; Rauert, C.; Su, K.; Smyth, S.-A.; Harner, T., Emission of poly and perfluoroalkyl substances, UV-filters and siloxanes to air from wastewater treatment plants. Environmental Pollution 2016, 218, 595-604.

10. Rauert, C.; Shoieb, M.; Schuster, J. K.; Eng, A.; Harner, T., Atmospheric concentrations and trends of poly- and perfluoroalkyl substances (PFAS) and volatile methyl siloxanes (VMS) over 7 years of sampling in the Global Atmospheric Passive Sampling (GAPS) network. Environmental Pollution 2018, 238, 94-102.

11. Lu, Z.; Martin, P. A.; Burgess, N. M.; Champoux, L.; Elliott, J. E.; Baressi, E.; De Silva, A. O.; de Solla, S. R.; Letcher, R. J., Volatile Methylsiloxanes and Organophosphate Esters in the Eggs of European Starlings (Sturnus vulgaris) and Congeneric Gull Species from Locations across Canada. Environmental Science \& Technology 2017, 51 (17), 9836-9845.

12. Sinanoglou, V. J.; Strati, I. F.; Miniadis-Meimaroglou, S., Lipid, fatty acid and carotenoid content of edible egg yolks from avian species: A comparative study. Food Chemistry 2011, 124 (3), 971-977.

13. Christie, W. W.; Moore, J. H., The lipid composition and triglyceride structure of eggs from several avian species. Comparative Biochemistry and Physiology Part B: Comparative Biochemistry 1972, 41 (2), 297-306.

14. Haedrich, J.; Stumpf, C.; Denison, M. S., Rapid extraction of total lipids and lipophilic POPs from all EU-regulated foods of animal origin: Smedes' method revisited and enhanced. Environmental Sciences Europe 2020, 32 (1), 118.

15. Sahasrabudhe, M. R.; Delorme, N. F.; Wood, D. F.; Randall, C. J., Neutral and Polar Lipids in Chicken Parts and Their Fatty Acid Composition1. Poultry Science 1985, 64 (5), 910-916.

16. Mourot, J.; Hermier, D., Lipids in monogastric animal meat. Reprod Nutr Dev 2001, 41 (2), 109118.

17. Katz, M. A.; Dugan Jr., L. R.; Dawson, L. E., Fatty Acids in Neutral Lipids and Phospholipids from Chicken Tissues. Journal of Food Science 1966, 31 (5), 717-720. 
18. Marion, J. E.; Woodroof, J. G., Lipid Fractions of Chicken Broiler Tissues and Their Fatty Acid Composition. Journal of Food Science 1965, 30 (1), 38-43.

19. Albro, P. W.; Schroeder, J. L.; Corbett, J. T., Lipids of the earthworm Lumbricus terrestris. Lipids 1992, 27 (2), 136-143.

20. Fast, P. G., A comparative study of the phospholipids and fatty acids of some insects. Lipids 1966, 1 (3), 209-15.

21. Gilby, A. R., Lipids and Their Metabolism in Insects. Annual Review of Entomology 1965, 10 (1), 141-160.

22. Nikolova, N.; Rezankab, T.; Nikolova-Damyanova, B. In Fatty Acid Profiles of Main Lipid Classes in Adult Chrysomela vigintipunctata (Scopoli) (ColeopteraiChrysomelidae), 2013.

23. Government of Canada Historical Climate Data - Vancouver International Airport, BC. (accessed May 9, 2021).

24. Atapattu, S. N.; Poole, C. F., Determination of descriptors for semivolatile organosilicon compounds by gas chromatography and non-aqueous liquid-liquid partition. Journal of Chromatography A 2009, 1216 (45), 7882-7888.

25. Ulrich, N.; Endo, S.; Brown, T. N.; Watanabe, N.; Bronner, G.; Abraham, M. H.; Goss, K. U., UFZ-LSER database v 3.22017.

26. $\mathrm{Xu}, \mathrm{S}$.; Kropscott, B., Evaluation of the three-phase equilibrium method for measuring temperature dependence of internally consistent partition coefficients (KOW, KOA, and KAW) for volatile methylsiloxanes and trimethylsilanol. Environmental Toxicology and Chemistry 2014, 33 (12), 2702-2710. 27. Harner, T.; Bidleman, T. F., Measurements of Octanol-Air Partition Coefficients for Polychlorinated Biphenyls. Journal of Chemical \& Engineering Data 1996, 41 (4), 895-899.

28. Shoeib, M.; Harner, T., Using measured octanol-air partition coefficients to explain environmental partitioning of organochlorine pesticides. Environmental Toxicology and Chemistry 2002, 21 (5), 984-990. 29. McNab, B., An Analysis of the Body Temperatures of Birds. The Condor 1966, 68.

30. Gessaman, J. A.; Hoffman, S. W., Body Temperatures of Migrant Accipiter Hawks Just after Flight. The Wilson Bulletin 1990, 102 (1), 133-137.

31. Prinzinger, R.; Preßmar, A.; Schleucher, E., Body temperature in birds. Comparative Biochemistry and Physiology Part A: Physiology 1991, 99 (4), 499-506.

32. Rybalov, L.; Rossolimo, T.; Block, W. In Temperature Adaptations of Terrestrial Arthropods of the Yenisey Region of Siberia (Asian Ecological Transect), Personal, societal, and ecological values of wilderness: Sixth World Wilderness Congress Bangalore, India, Watson, A. E.; Aplet, G. H.; Hendee, J. C., Eds. U.S.Department of Agriculture, Forest Service, Rocky Mountain Research Station: Bangalore, India, 2000.

33. Daniel, O.; Kohli, L.; Bieri, M., Weight gain and weight loss of the earthworm Lumbricus terrestris L. at different temperatures and body weights. Soil Biology and Biochemistry 1996, 28 (9), 1235-1240.

34. Reynolds, J. W., Earthworms of the world. Global Biodiversity 1994, 4 (1), 11-16.

35. Gatehouse, S. N.; Markham, B. J., Respiratory Metabolism of Three Species of Raptors. The Auk 1970, 87 (4), 738-741.

36. Rosenfield, R. N.; Madden, K. K.; Bielefeldt, J.; Curtis, O. E., Cooper's Hawk (Accipiter cooperii), version 1.0. In Birds of the World, Rodewald, P. G., Ed. Cornell Lab of Ornithology: Ithaca, NY, USA, 2020.

37. Bishop, C. M., The maximum oxygen consumption and aerobic scope of birds and mammals: getting to the heart of the matter. Proc Biol Sci 1999, 266 (1435), 2275-2281.

38. Butler, P. J., The physiological basis of bird flight. Philosophical transactions of the Royal Society of London. Series B, Biological sciences 2016, 371 (1704), 20150384.

39. Curtis, O. E.; Rosenfield, R. N.; Bielefeldt, J., Cooper's Hawk (Accipiter cooperii). In The Birds of North America, Rodewald, P. G., Ed. Cornell Lab of Ornithology: Ithaca, 2006.

40. Cabe, P. R., European Starling (Sturnus vulgaris). In The Birds of North America, Rodewald, P. G., Ed. Cornell Lab of Ornithology: Ithaca, 1993. 
41. Roth, T. C.; Lima, S. L.; Boal, C. W., Predatory behavior and diet of wintering male Cooper's hawks in a rural habitat. Journal of Raptor Research 2006, 40 (4), 287-290.

42. Estes, W. A.; Mannan, R. W., Feeding Behavior of Cooper's Hawks at Urban and Rural Nests in Southeastern Arizona. The Condor 2003, 105 (1), 107-116.

43. Cava, J. A.; Stewart, A. C.; Rosenfield, R. N., Introduced species dominate the diet of breeding urban Cooper's hawks in British Columbia. The Wilson Journal of Ornithology 2012, 124 (4), 775-782.

44. Currier, H. A.; Fremlin, K. M.; Elliott, J. E.; Drouillard, K. G.; Williams, T. D., Bioaccumulation and biomagnification of PBDEs in a terrestrial food chain at an urban landfill. Chemosphere 2020, 238, 124577.

45. Fischl, J.; Caccamise, D. F., Relationships of Diet and Roosting Behavior in the European Starling. The American Midland Naturalist 1987, 117 (2), 395-404.

46. Tinbergen, J. M., Foraging decisions in Starlings (Sturnus vulgaris L.). Ardea 1980, 69, 1-67.

47. Dekant, W.; Klaunig, J. E., Toxicology of decamethylcyclopentasiloxane (D5). Regulatory Toxicology and Pharmacology 2016, 74, S67-S76.

48. Franzen, A.; Greene, T.; Van Landingham, C.; Gentry, R., Toxicology of octamethylcyclotetrasiloxane (D4). Toxicology Letters 2017, 279, 2-22.

49. Domoradzki, J. Y.; Sushynski, C. M.; Sushynski, J. M.; McNett, D. A.; Van Landingham, C.; Plotzke, K. P., Metabolism and disposition of [14C]-methylcyclosiloxanes in rats. Toxicology Letters 2017, 279, 98-114.

50. Drouillard, K. G.; Norstrom, R. J., Dietary absorption efficiencies and toxicokinetics of polychlorinated biphenyls in ring doves following exposure to aroclor ${ }^{\circledR}$ mixtures. Environmental Toxicology and Chemistry 2000, 19 (11), 2707-2714. 
\#Fugacity based trophic magnification factors characterize

bioaccumulation of cyclic methyl siloxanes within an urban terrestrial

avian food web: Importance of organism body temperature and composition

\#Fremlin, K.M., J.E. Elliott, P. A. Martin, T. Harner, A. Saini, and F.A.P.C. Gobas

\#Supplementary Information - Monte Carlo Simulation R Code

\#Lines : 708

\#Monte Carlo Flux simulations

library (tidyverse)

library (dplyr)

\#Cooper's hawk

\#D4 dietary flux

\#\# weight wet concentration converted to $\mathrm{mol} / \mathrm{m} 3$

diet. $\mathrm{D} 4$.results $=$ NULL

for $(\mathrm{k}$ in $1: 10000)\{$

Flow $=$ runif $(1,0.00006,0.000075)$

\#assuming uniform dist as all flow values have equal chance of occuring

Concentration $=\operatorname{rlnorm}(1$, meanlog=-12.27, $\operatorname{sdlog}=0.33)$

\#assuming log norm dist with mean concentration value

Uptake $=\operatorname{runif}(1,0.7,1)$

\#assuming uniform dist as all uptake efficiency values have equal

chance of occuring

diet. $\mathrm{D} 4$.results $=r b i n d(x=$ diet.$D 4$.results,

data.frame (Flow, Concentration, Uptake))

\}

diet. $\mathrm{D} 4$.results $\$ \mathrm{Flux}=$ diet. $\mathrm{D} 4$.results $\$ \mathrm{Flow}$

*diet.D4.results\$Concentration * diet.D4.results\$Uptake

diet. $D 4$.results $\$ \log F \operatorname{lux}=\log ($ diet. $D 4$.results $\$ F l u x$ )

summary (diet.D4.results)

summarize (diet. D4.results, LogMean=mean ( $\log F \operatorname{lux})$,

LogSD $=\operatorname{sd}(\log F \operatorname{lux})$,

LogSEM $=$ LogSD $/$ sqrt $(10000)$,

LogLCL $=$ LogMean $-1.96 * \operatorname{LogSD}$,

LogUCL $=$ LogMean $+1.96 *$ LogSD,

Mean $=\exp ($ LogMean $)$,

$\mathrm{SD}=\exp ($ LogMean $) * \log S \mathrm{D}$,

SEM $=\exp ($ LogMean $) *$ LogSEM ,

LCL $=\exp (\operatorname{LogLCL})$,

$\mathrm{UCL}=\exp (\log U C L))$

ggplot (diet.D4.results, aes $(\mathrm{x}=(\log F \operatorname{lux})))+$ geom_histogram() 


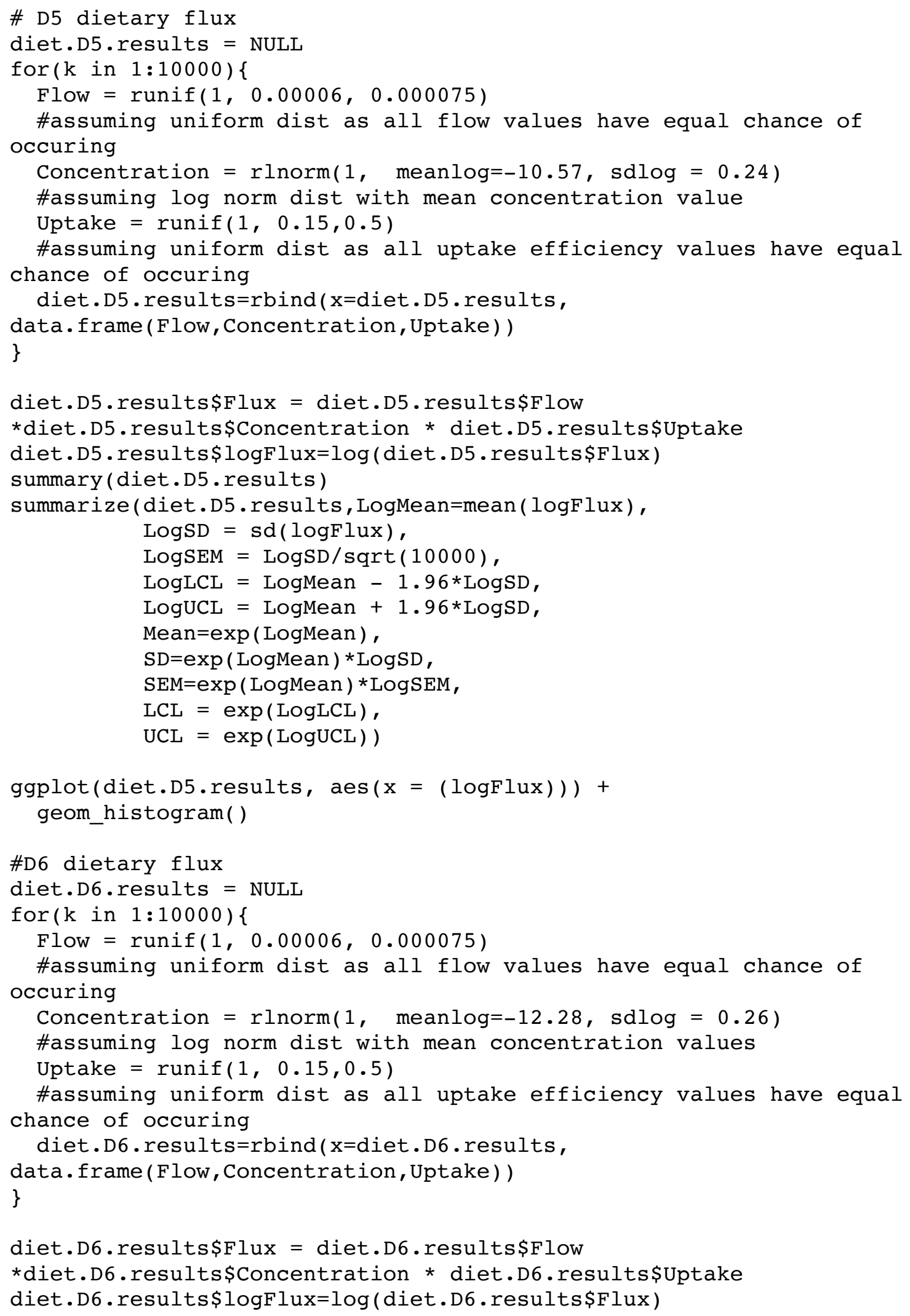




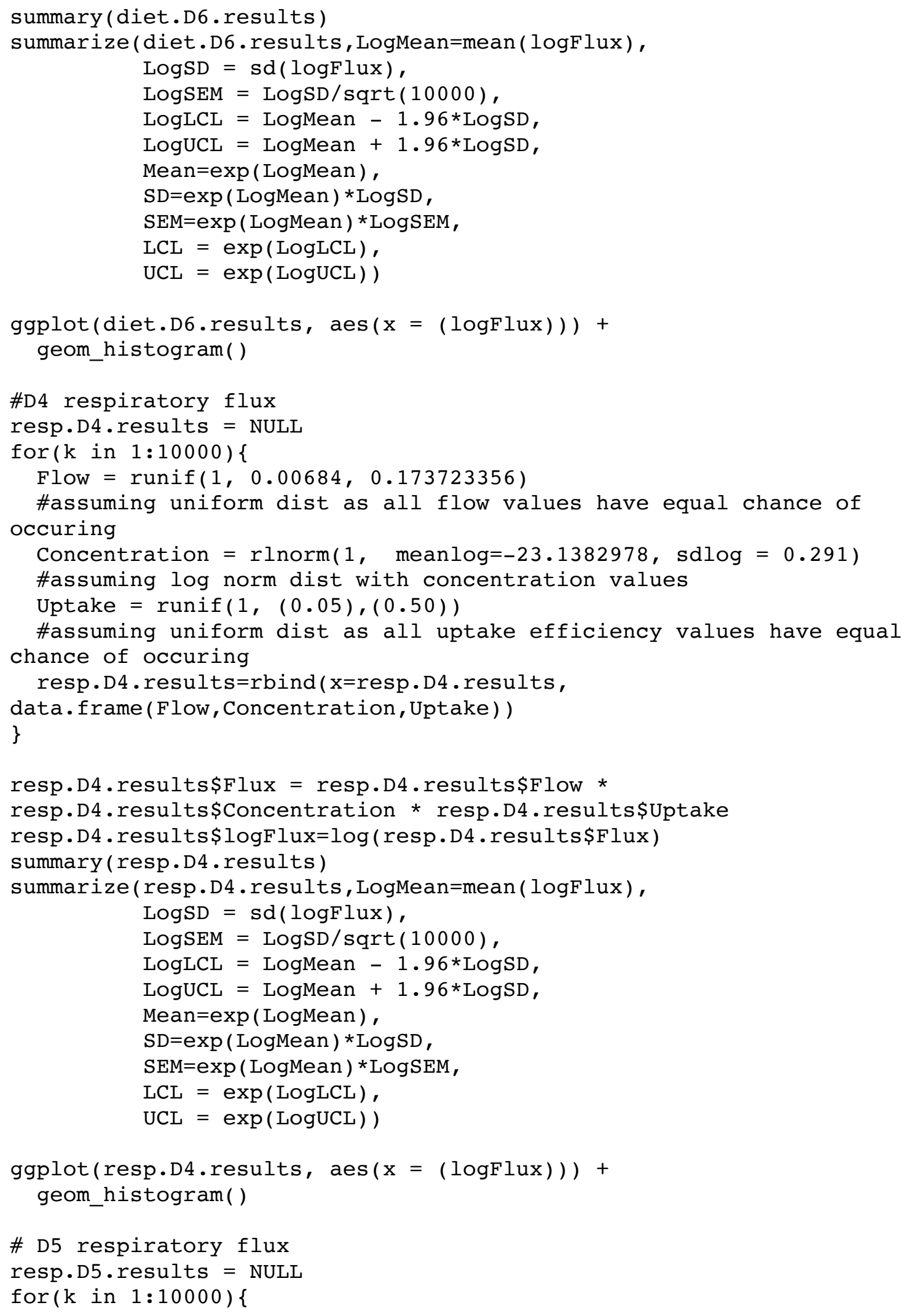




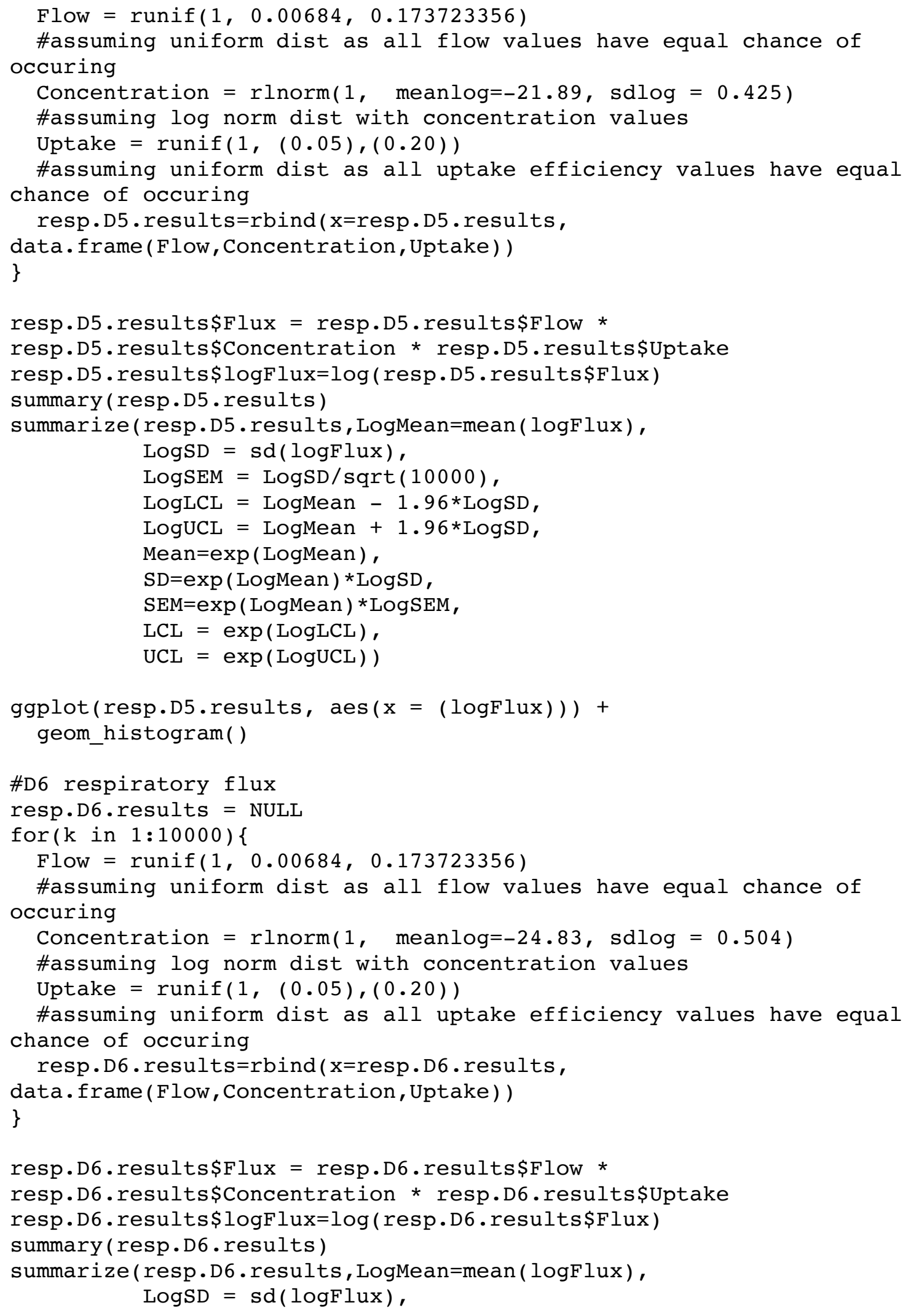




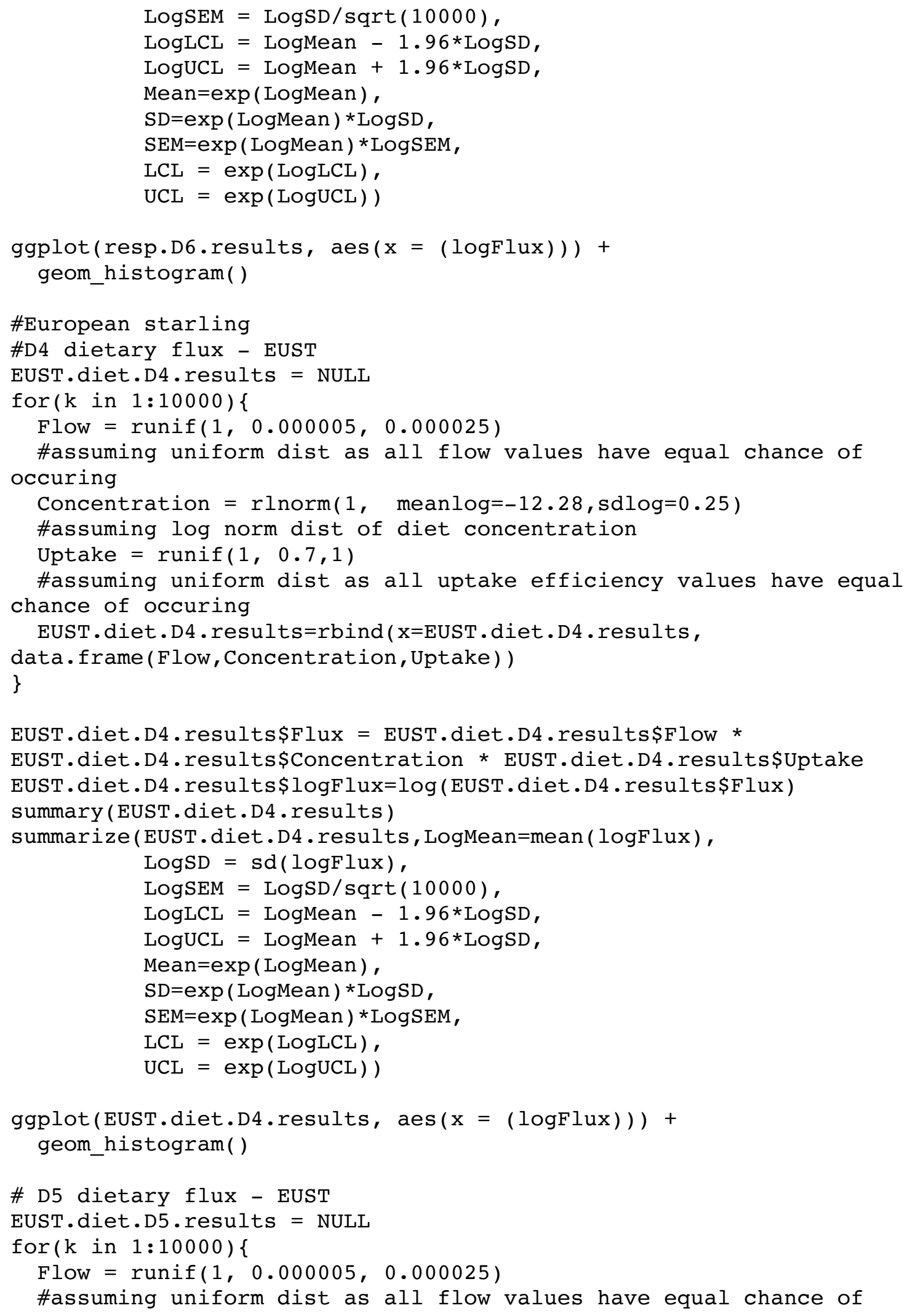




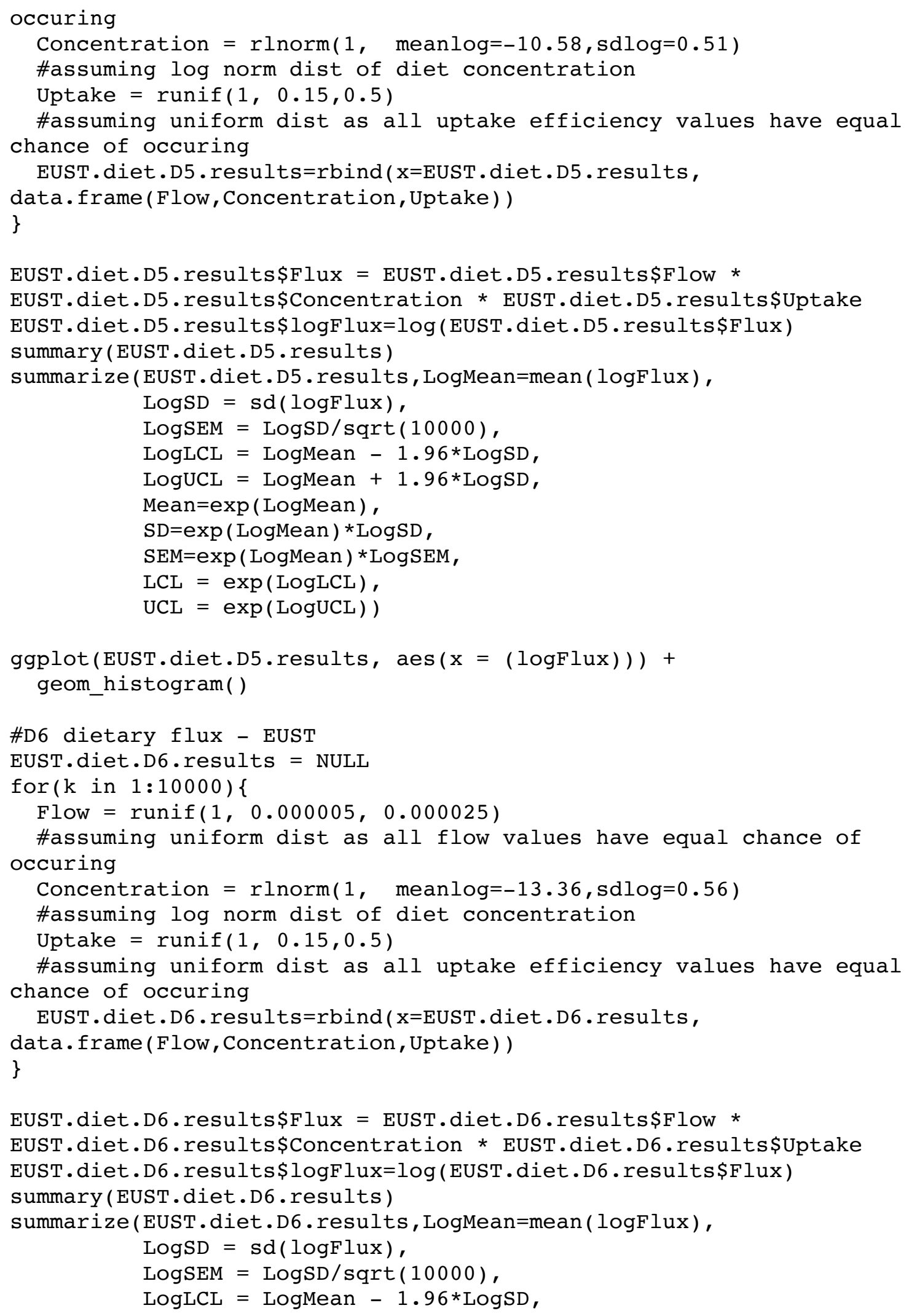


\#assuming log norm dist with concentration values

Uptake $=\operatorname{runif}(1,0.05,0.20)$

\#assuming uniform dist as all uptake efficiency values have equal chance of occuring

EUST.resp.D5.results=rbind ( $x=$ EUST . resp.D5 .results, data. frame (Flow, Concentration, Uptake)) \}

EUST.resp.D5.results\$Flux = EUST.resp.D5.results\$Flow* EUST.resp.D5.results\$Concentration* EUST.resp.D5.results\$Uptake EUST.resp.D5.results $\$ \log F \operatorname{lux}=\log$ (EUST.resp.D5.results $\$ F l u x$ ) summary (EUST.resp.D5.results) summarize (EUST . resp.D5 . results, LogMean=mean ( logFlux), LogSD $=\operatorname{sd}(\log F \operatorname{lux})$, LogSEM $=$ LogSD/sqrt $(10000)$, LogLCL $=$ LogMean $-1.96 *$ LogSD, LogUCL $=$ LogMean $+1.96 *$ LogSD, Mean $=\exp ($ LogMean $)$, $\mathrm{SD}=\exp ($ LogMean $) * \log S \mathrm{D}$, SEM $=\exp ($ LogMean $) *$ Log SEM , $L C L=\exp (\log L C L)$, $\mathrm{UCL}=\exp (\log U C L))$

ggplot(EUST.resp.D5.results, aes $(x=(\operatorname{logFlux})))+$ geom_histogram()

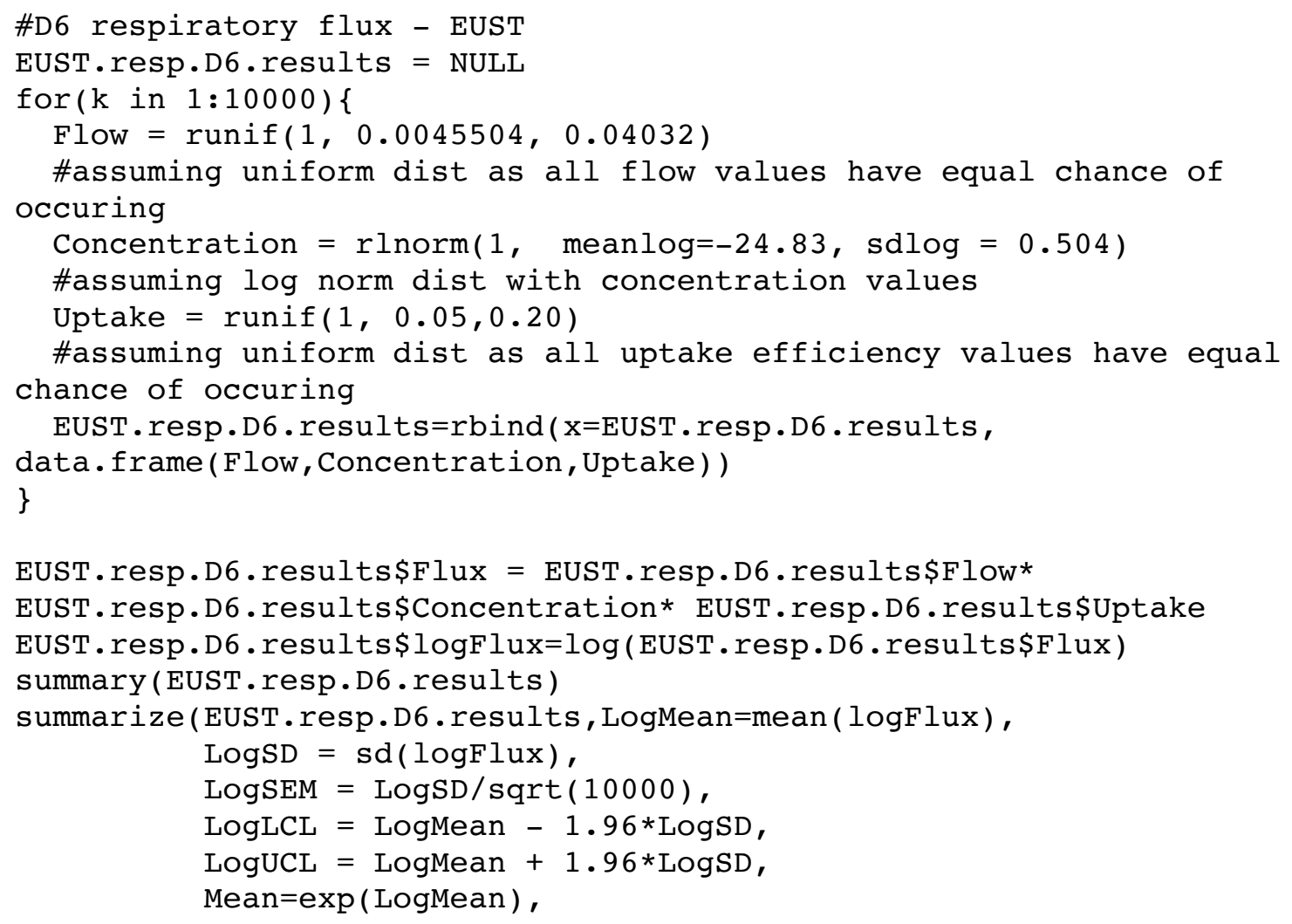




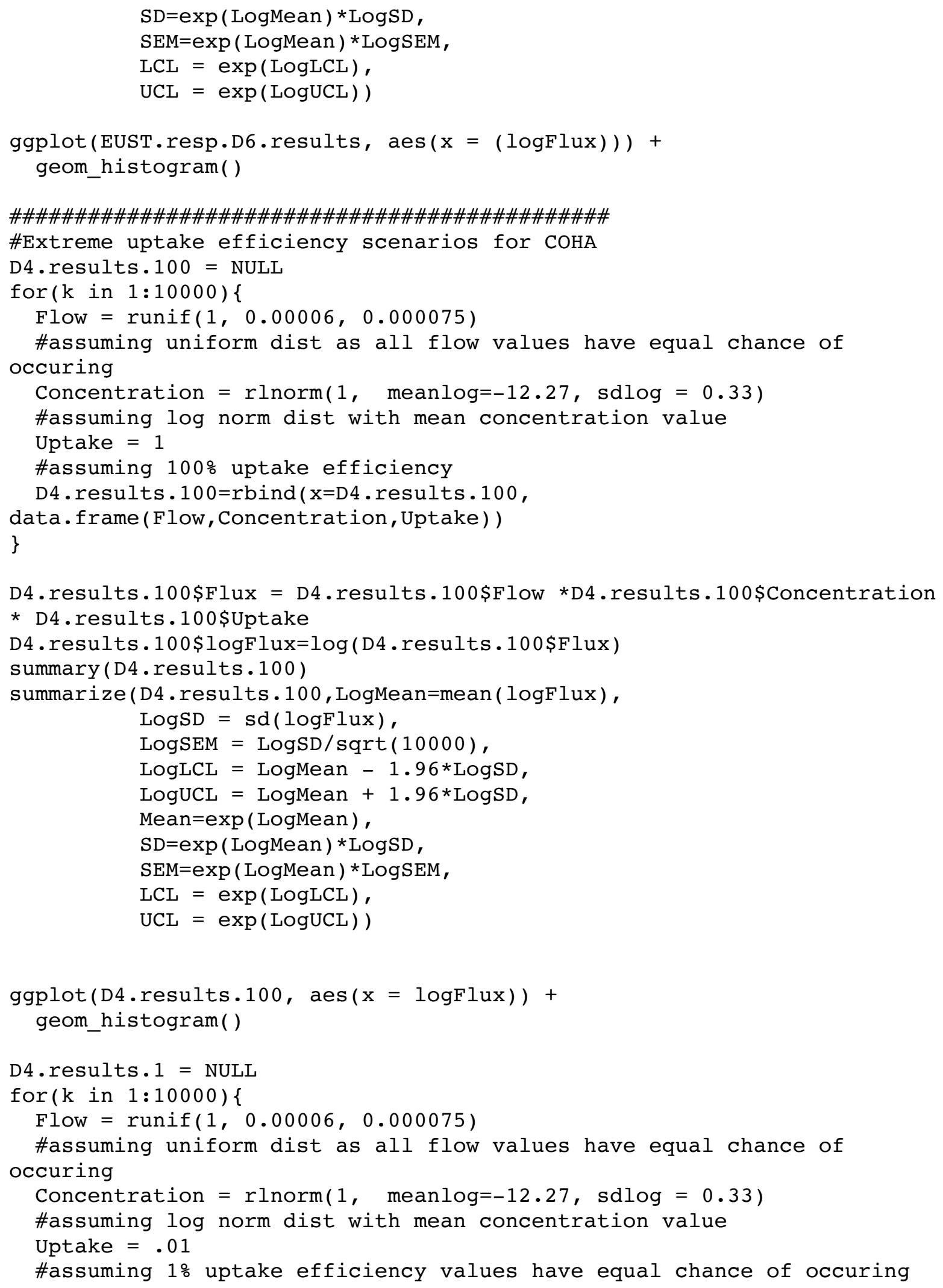




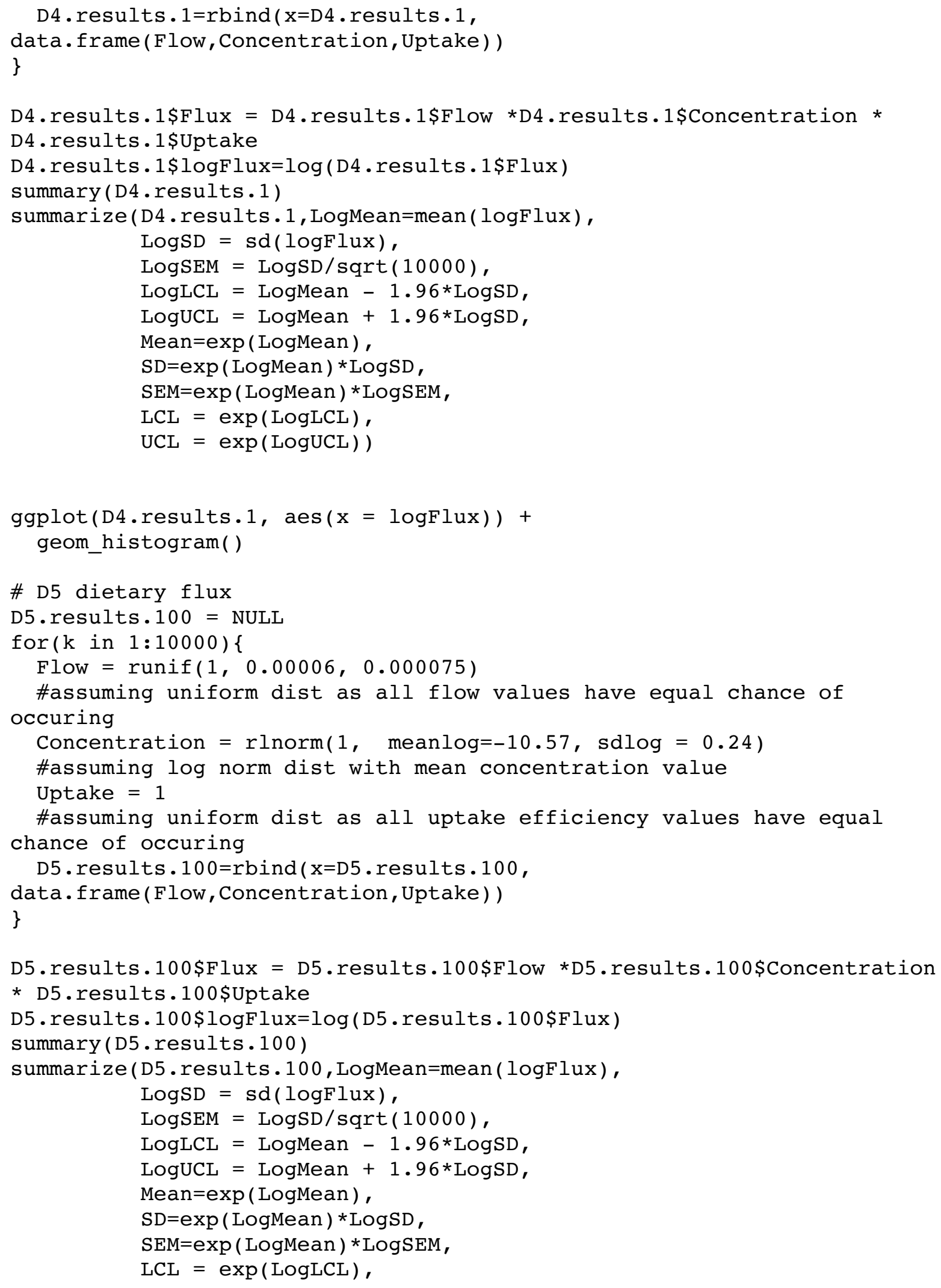




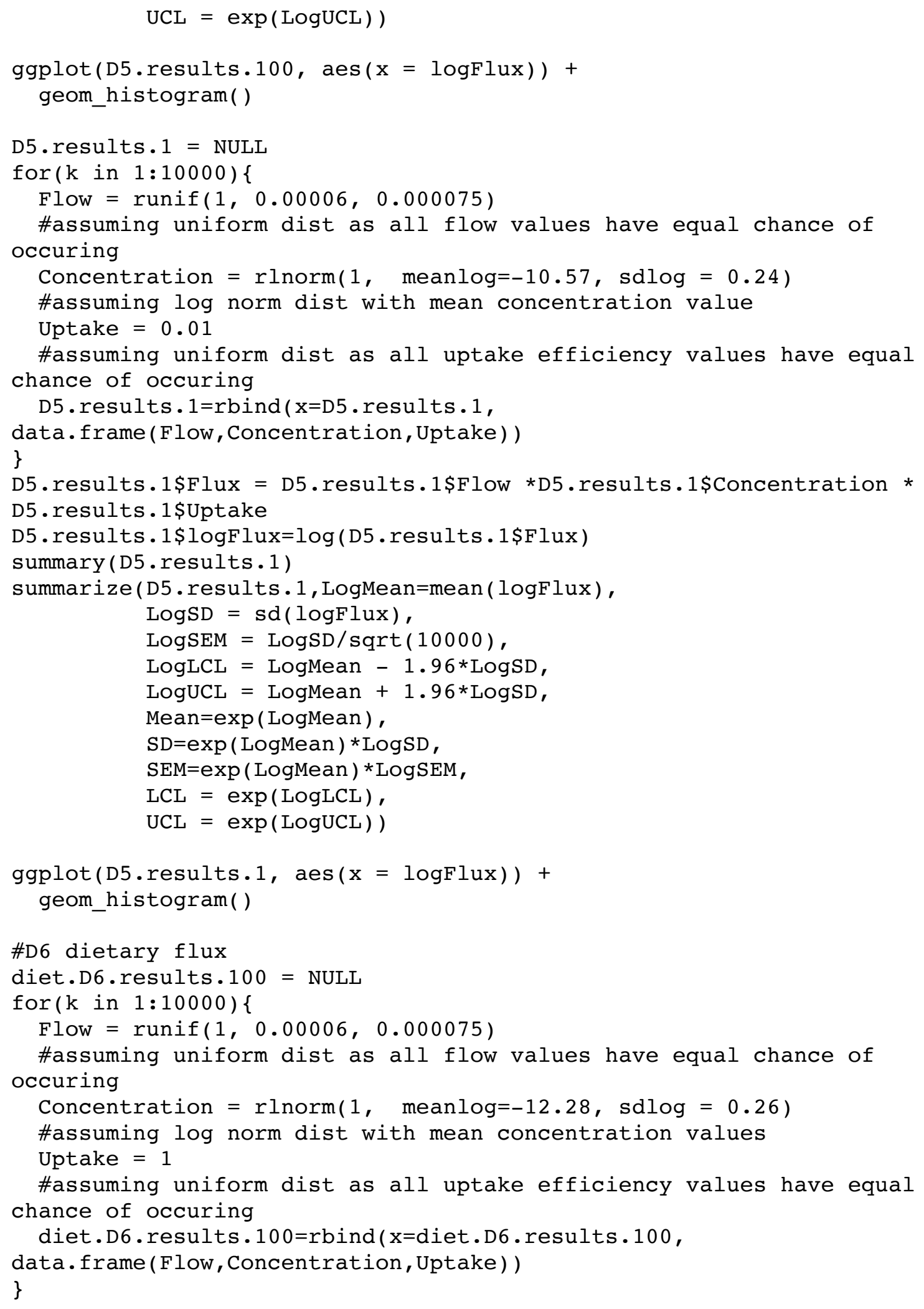


diet.D6.results.100\$Flux = diet.D6.results. 100 Flow

*diet.D6.results.100\$Concentration * diet.D6.results.100\$Uptake

diet.D6.results.100\$logFlux=log (diet.D6.results. $100 \$ F l u x$ )

summary (diet.D6.results.100)

summarize (diet.D6.results.100, LogMean=mean ( logFlux),

LogSD $=\operatorname{sd}(\log F \operatorname{lux})$,

LogSEM $=\mathrm{LogSD} /$ sqrt $(10000)$,

LogLCL $=$ LogMean $-1.96 * \operatorname{LogSD}$,

LogUCL $=$ LogMean $+1.96 *$ LogSD,

Mean $=\exp ($ LogMean $)$,

$\mathrm{SD}=\exp ($ LogMean $) * \log S D$,

$\mathrm{SEM}=\exp ($ LogMean $) *$ LogSEM ,

LCL $=\exp ($ LOgLCL $)$,

$\mathrm{UCL}=\exp (\log U C L))$

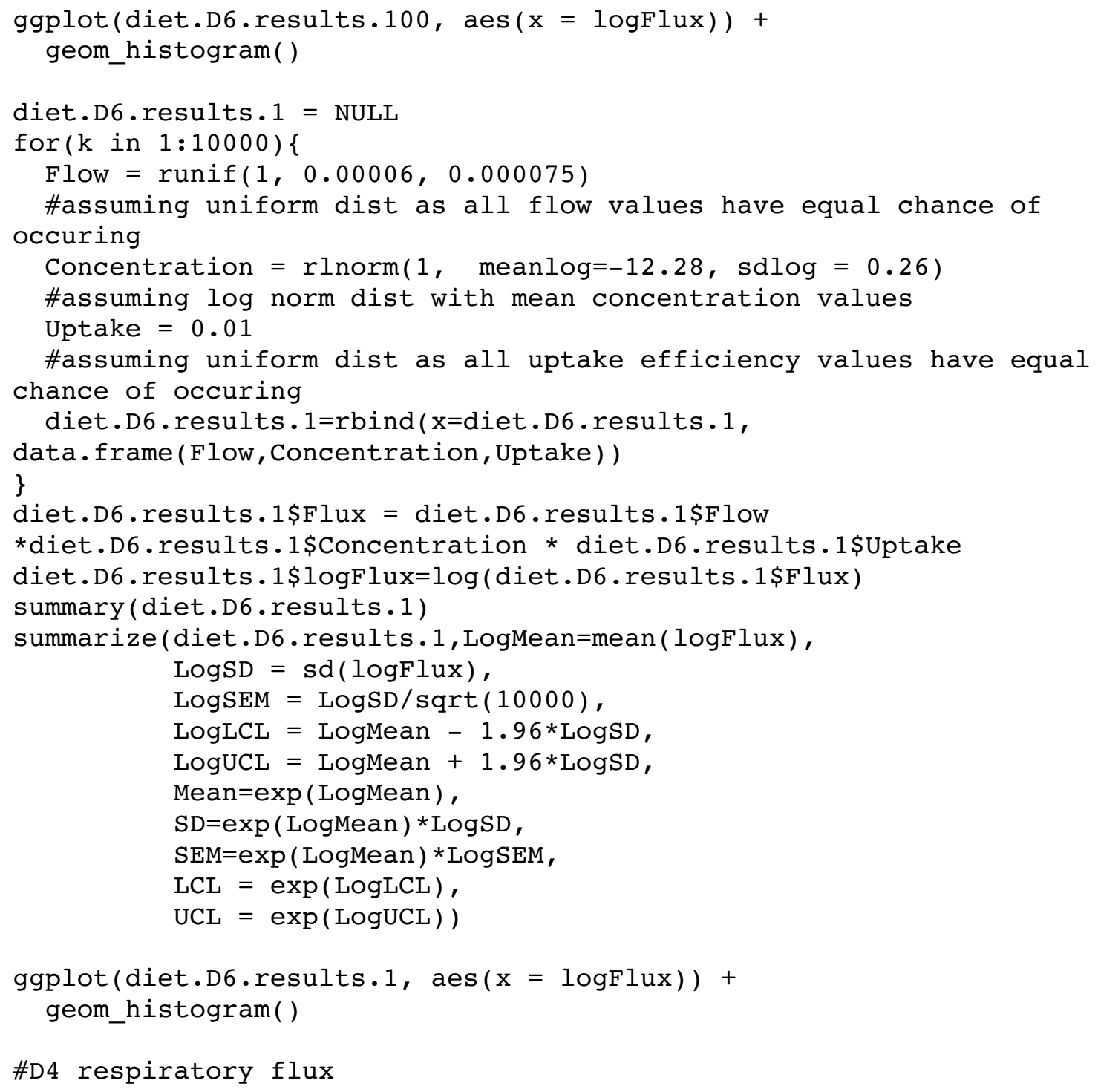




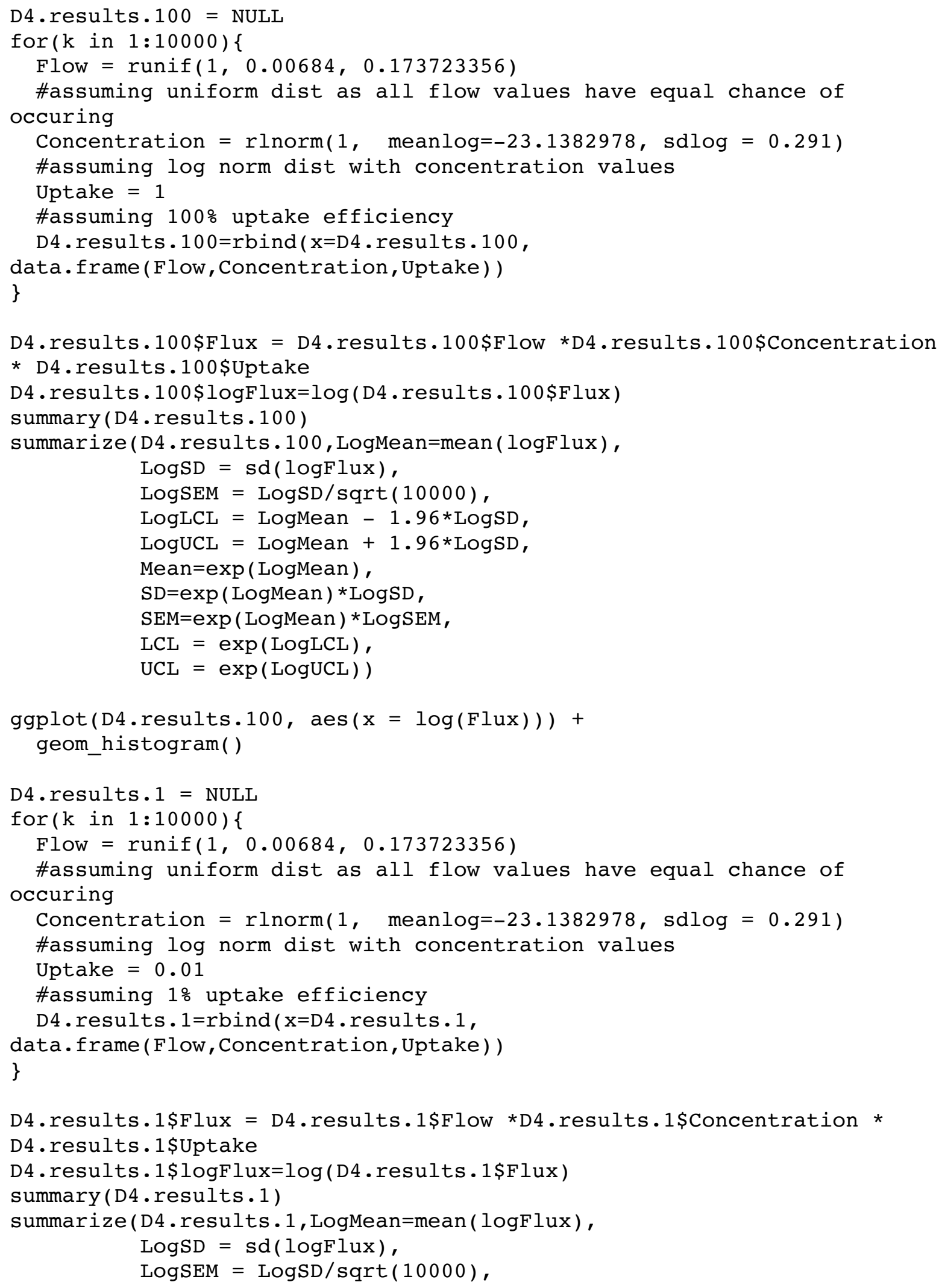




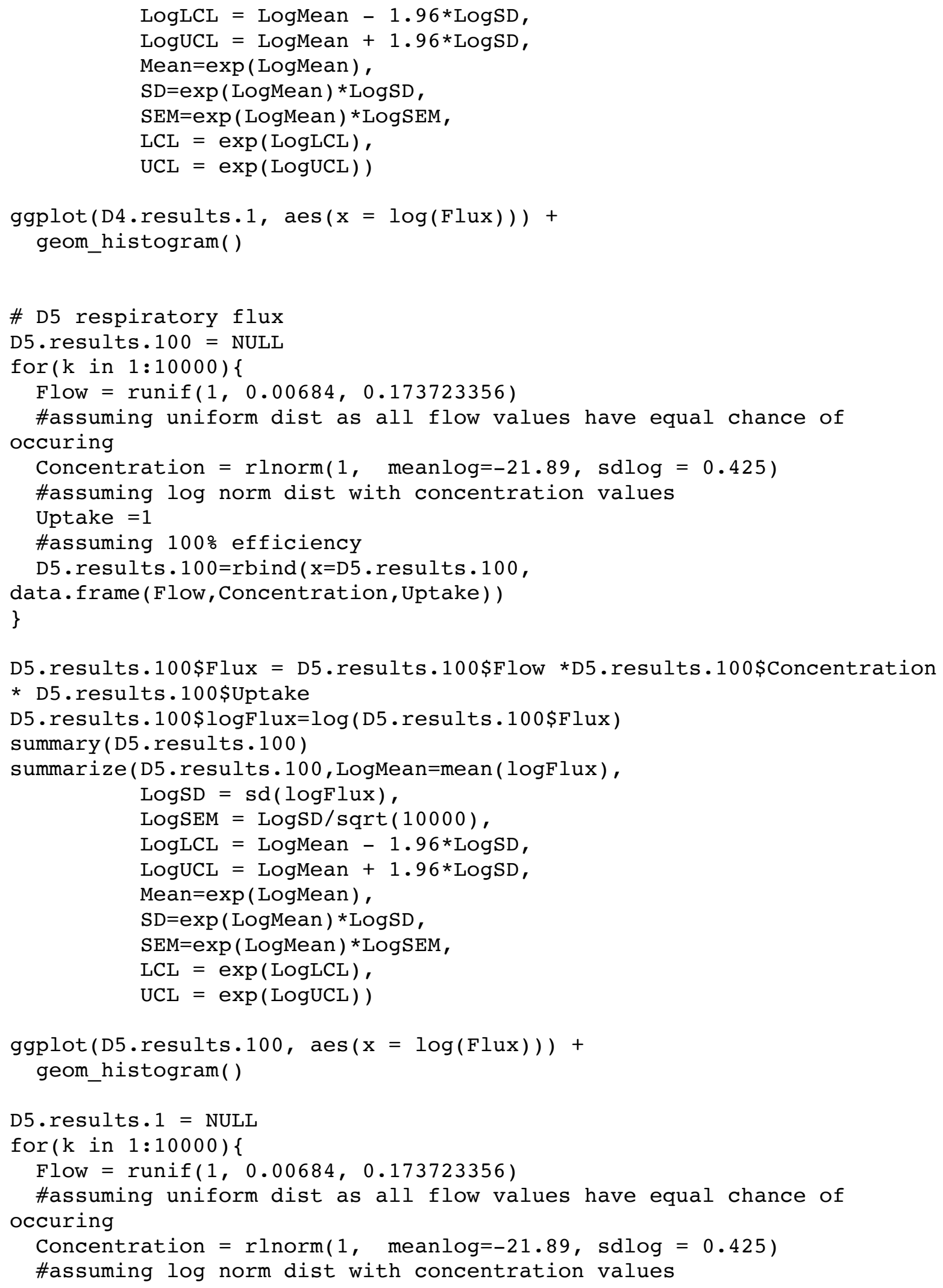




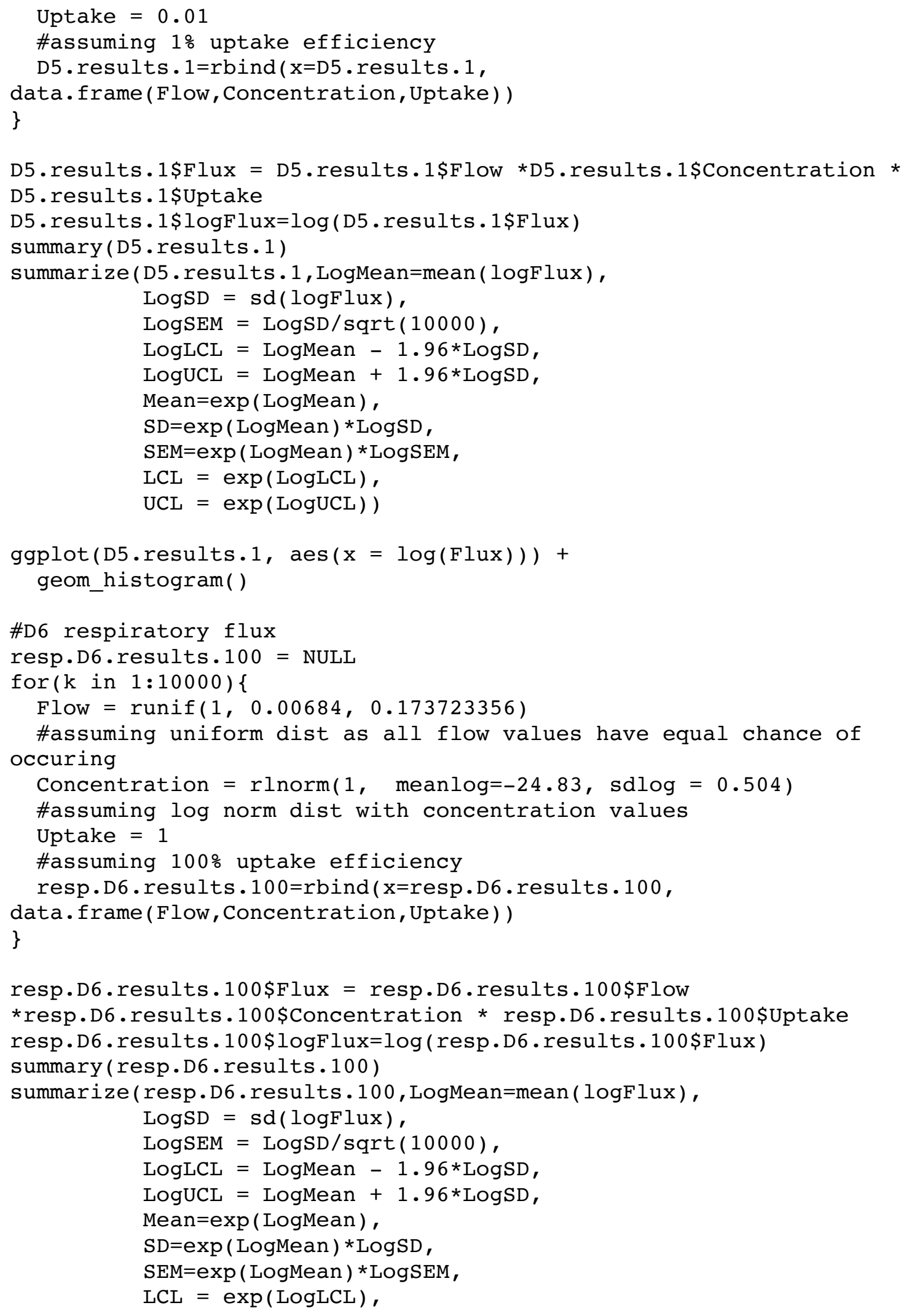




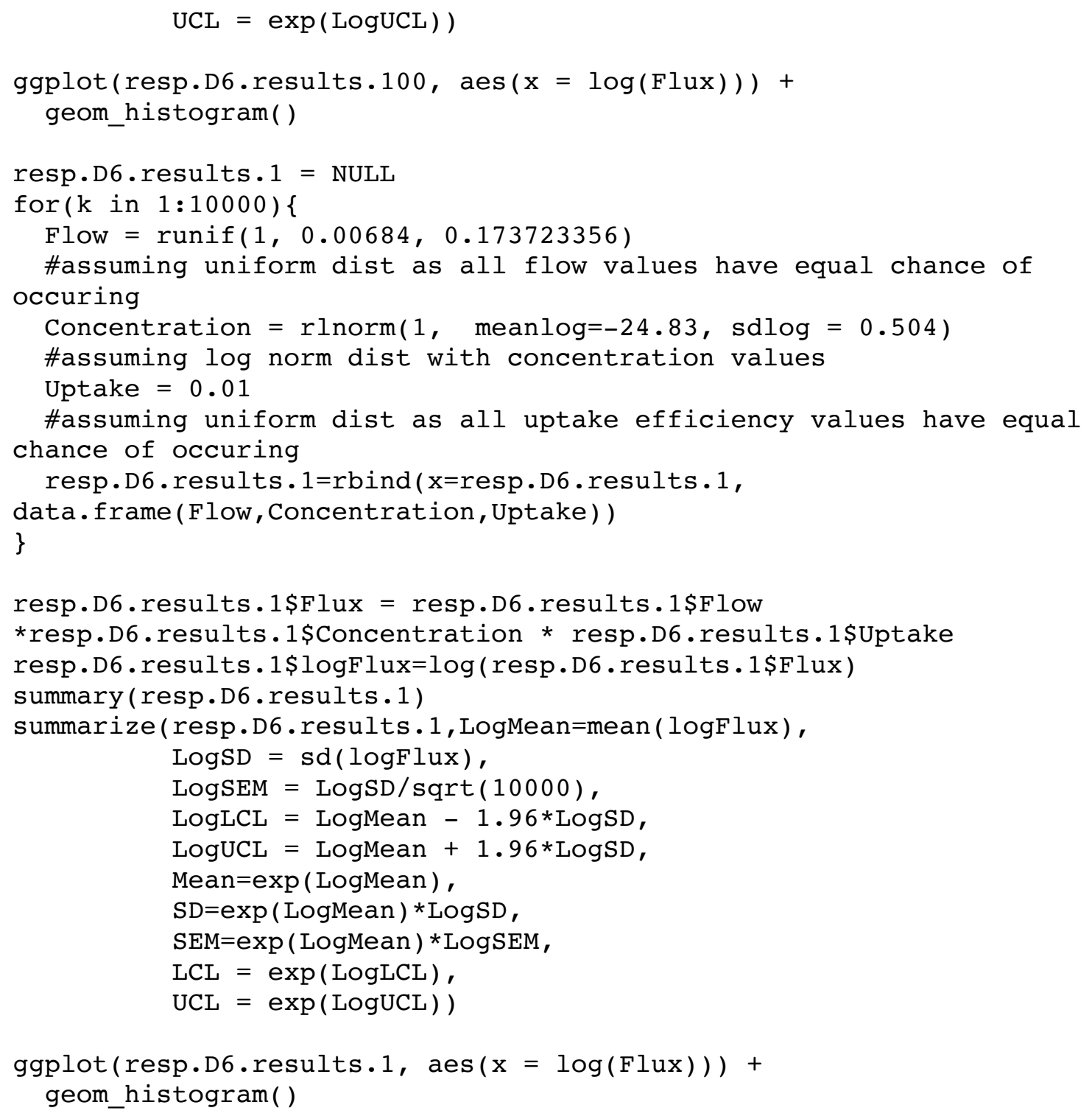


Author: Kate M. Fremlin

Date: June 13, 2021

Description: Details and information about raw data provided for Fremlin et al. 2021.

Fugacity based trophic magnification factors characterize bioaccumulation of cyclic methyl siloxanes within an urban terrestrial avian food web: Importance of organism body temperature and composition.

City Region - Indicates general location in Metro Vancouver, BC that sample was collected in

Sample ID - Indicates the laboratory or field identification for a sample

Species - Species or species group of sample

Dry Matter (\%) - Fraction of total dry matter in the sample, based on $100 \%$ minus Moisture

Moisture (\%) - Fraction of total moisture in the sample, based on wet weight

Lipids (\%) - Fraction of total lipid content in the sample, based on wet weight

Polar Lipids (\%) - Fraction of total polar lipids (i.e. phospholipids) in the sample, based on wet weight

Non-polar Lipids (\%) - Fraction of total non-polar lipids in the sample, based on total lipids minus polar lipids

Protein (\%) - Fraction of total protein in the sample, based on wet weight

Organic Matter (\%) - Fraction of organic matter in the sample, based on dry matter minus protein minus total lipids

$\delta 13 C(\%)-$ Fraction of carbon 13 stable isotope in the sample, based on dry weight C (\%) - Fraction of elemental carbon in the sample, based on dry weight $\delta 15 \mathrm{~N}(\%)$ - Fraction of nitrogen 15 stable isotope in the sample, based on dry weight $\mathrm{N}(\%)$ - Fraction of elemental nitrogen in the sample, based on dry weight TP - Trophic position of the sample based on stable isotope comparisons and calculation, see Fremlin et al. 2020 for more details

D4 - Blank corrected wet weight concentration (ng/g) of D4 in the sample

D5 - Blank corrected wet weight concentration (ng/g) of D5 in the sample 
D6 - Blank corrected wet weight concentration $(\mathrm{ng} / \mathrm{g})$ of D6 in the sample

DDE - Blank corrected wet weight concentration (ng/g) of $p, p-D D E$ in the sample

PCB-153 - Blank corrected wet weight concentration (ng/g) of PCB-153 in the sample 